\title{
Applications of Supercritical Fluids in Latin America: Past, Present and Future Trends
}

\author{
Moyses N. Moraes, Giovani L. Zabot, M. Angela A. Meireles* \\ LASEFI/DEA/FEA (School of Food Engineering)/UNICAMP (University of Campinas); Rua Monteiro Lobato, 80; Campinas-SP; \\ CEP:13083-862; Brazil
}

\begin{abstract}
Latin America possesses expansive natural resources, which has attracted scientists from several areas to study means of improving the use of these resources. Supercritical fluids have been used for such purposes in many technological applications. Therefore, this paper provides an overview of Latin America scientific findings on supercritical technologies. Web of Science and Scopus were used as reference databases to search for information dated from 2004-2013. The Latin-American studies were classified into 6 main areas: extraction \& mathematical modeling (57\%), emerging applications $(15 \%)$, thermodynamics \& fundamentals $(9 \%)$, reviews \& perspectives $(8 \%)$, reactions in supercritical media $(7 \%)$ and analytical applications (4\%). A compilation of scientific documents from 1994-2003 indicates that supercritical technology has progress greatly over the last 10 years in the major scientific countries in Latin America, such as Brazil, Argentina, Chile, Mexico and Colombia. These advances are associated with the development of new research subjects. Emerging applications, such as micronization and the encapsulation of nanoparticles, adsorption processes, gas sensors development, power generation and bioresidue hydrolyzation, are reported.
\end{abstract}

Keywords Latin america, Supercritical fluids, Emerging applications, Reactions, Micronization, Particle formation

\section{Introduction}

Latin America (LA) consists of 33 countries: Antigua and Barbuda, Argentina, Bahamas, Barbados, Belize, Bolivia, Brazil, Chile, Colombia, Commonwealth of Dominica, Costa Rica, Cuba, Dominican Republic, Ecuador, El Salvador, Granada, Guatemala, Guyana, Haiti, Honduras, Jamaica, Mexico, Nicaragua, Panama, Paraguay, Peru, Saint Kitts, Saint Vincent and The Grenadines, Santa Lucia, Suriname, Trinidad and Tobago, Uruguay, and Venezuela.

Advances in the research \& development sectors of these countries have been mentioned by several scientists, such as del Valle et al [1] and Crespi and Zuniga [2]. Many applications are being reported for supercritical technologies from the study of fundamental thermodynamics [3] to emerging applications such as nanoparticle production and encapsulation [4]. Supercritical fluids are of interest to the global scientific community because of their special properties (e.g., low viscosity, high diffusivity and large solubilization capacity), which makes these fluids preferable to organic solvents. Furthermore, products obtained using supercritical technologies are free of toxic residues and possess high quality.

\footnotetext{
* Corresponding author:

meireles@fea.unicamp.br (M. Angela A. Meireles)

Published online at http://journal.sapub.org/fph

Copyright (C) 2014 Scientific \& Academic Publishing. All Rights Reserved
}

The rich biodiversity of some countries in LA provides numerous natural pigments (found in roots, aromatic herbs, leaves, seeds and tropical fruits for instance). The food, cosmetic, pharmaceutical and chemical industries are all interested in these pigments.

In this context, the use of supercritical fluids in several processes has increased over the last few years. Nonetheless, in LA, these processes are still being developed on the laboratory or pilot scales. The challenge is transferring knowledge acquired via scientific investigations to the industrial scale to show potential for supercritical technologies to overcome their implementation costs.

In 2005, Rosa and Meireles [5] presented the historical insertion/evolution of supercritical technologies in Brazil and summarized the South America contribution to this field from 1994-2003. Therefore, the present article was written to update this contribution and expand it to all LA countries. The objective is to emphasize the emergence of novel research programs focusing on processes integration, such as micronization of functional pigments, hydrolyzation of supercritical fluid extraction co-products, performance of reactions in supercritical media and application of supercritical fluids to energy.

\section{Supercritical Technology in Latin America}

This section details supercritical fluid applications in LA 
from 2004 to 2013. Web of Science and Scopus (two large, global databases) were used to find and index published patents and Journal papers. A search was done using the term 'supercritical fluid*' and requiring the presence of one of the 33 countries listed above in the address field.

The Web of Science search returned 10,164 scientific documents for the period defined above with as many as 500 addressed to LA countries. To filter the responses, the word 'extraction' was combined with other terms as follows: 'supercritical fluid* extraction' or 'compressed carbon dioxide extraction' or 'pressurized carbon dioxide extraction' or 'pressurized $\mathrm{CO}_{2}$ ' or 'supercritical $\mathrm{CO}_{2}$ '. These searches returned 3,598 documents with as many as 286 linked to researchers associated with research centers and institutions from LA. These 286 documents were divided as follows: 254 papers published in Journals, 29 papers from conference proceedings, 2 patents and 1 book chapter.

The low contribution of patents in this search is related to their indexing in local (national) databases. The same justification is valid for papers published in conference proceedings. Furthermore, few book chapters are indexed by Web of Science.

The Scopus search returned 12,668 documents during 2004-2013 with as many as 534 addressed to LA. The same terms used with Web of Science were used for the filtered Scopus search. A total of 3,291 documents were found with as many as 195 linked to Latin-American scientists. The documents were divided as follows: 177 Journal papers and 18 conference proceeding papers.

Of the supercritical technology areas, extractions had the largest representation with approximately $55 \%$ of the published documents. However, supercritical fluid extraction (SFE) is still poorly diffused throughout the global scientific community, even with its significant growth after the 1990s. Based on the Web of Science search, before 1993 a total of 32,778 scientific documents were published for all extraction methods with only 211 correspond to SFE $(0.6 \%$ of the total). Over the last 20 years, 227,809 scientific documents were published for all extraction methods with 6,221 corresponding to SFE $(2.7 \%$ of the total). These findings mean the contribution of SFE around the world increased 4.5 times since 1993 relative to other methods.

Research in LA has been responsible for $2.5 \%$ of the worldwide publications on supercritical technology before 2010. In the past three years (2010-2013), the effort of Latin
American scientists and new supercritical fluid applications expanded the LA contribution to $4.8 \%$ of the worldwide publications.

To evaluate the importance of supercritical fluid processes to obtaining value-added products, Table 1 shows the evolution of publications addressed to LA over the last 10 years. The scientific investigations of the major scientific countries were classified into 6 groups: extraction \& mathematical modeling, emerging applications, thermodynamics \& fundamentals, reviews \& perspectives, reactions in supercritical media and analyses.

From 2004 to 2013, 15\% of scientific production comprised "emerging applications". Micronization, encapsulation, both precipitation and impregnation of nanomaterials, sensors development, biomass conversion into value-added products and energy are applications included in this area.

Many of these emerging applications have been studied with increasing intensity since 2008. For example, the research of Santos et al [6] studied the production of stabilized sub-micrometric carotenoid particles via supercritical $\mathrm{CO}_{2}$ extraction of an emulsion. This emerging and promising area combines supercritical $\mathrm{CO}_{2}$ with nano-emulsions to form and encapsulate nanoscale substances within the emulsions. The goal is to stabilize the target components to reduce their degradation rate in aqueous media. An illustrative flowchart of this process is shown in Scheme 1.

The first work in this area from LA and published by a Journal indexed in these two databases appeared in 2006 by Corazza et al [7]. Afterwards, in 2008, Franceschi et al [8] and Franceschi et al [9] studied the encapsulation of $\beta$-carotene and precipitation of theophylline, respectively. By July 2013, 8 other scientific documents had been published on this issue in LA [4], [6], [10-15], which indicates significant growth in this line of research.

In mid-2009, low-cost sensors were developed on paper by line patterning a graphite and polyaniline coating using supercritical $\mathrm{CO}_{2}$ [16], [17]. Under supercritical conditions, $\mathrm{CO}_{2}$ possesses low viscosity and low surface tension, which increases the uniformity of the polymer particles deposited on the surface. Furthermore, the properties of $\mathrm{CO}_{2}$ have made it a very promising fluid for improving the sensor performance and sensitivity [18]. One application indicated for these gas sensors is the detection of fruit ripeness as demonstrated for bananas [19].

Table 1. Number of publications (Web of Science) related to supercritical fluids from research in Latin American countries

\begin{tabular}{|c|c|c|c|c|c|c|c|c|c|c|c|}
\hline Area & 2004 & 2005 & 2006 & 2007 & 2008 & 2009 & 2010 & 2011 & 2012 & $2013 *$ & Total \\
\hline Analytical applications & - & 1 & 1 & 1 & - & 1 & - & 1 & 2 & 2 & 9 \\
\hline Emerging applications & 1 & 4 & 2 & 2 & 5 & 4 & 5 & 6 & 8 & 5 & 42 \\
\hline Extraction \& mathematical modeling & 4 & 13 & 12 & 14 & 20 & 20 & 18 & 22 & 28 & 12 & 163 \\
\hline Reactions in supercritical media & - & 2 & 1 & 3 & 2 & 2 & 1 & 2 & 3 & 5 & 21 \\
\hline Reviews \& perspectives & - & 3 & 2 & 2 & 2 & 4 & 3 & 2 & 5 & 1 & 24 \\
\hline Thermodynamics \& fundamentals & 6 & 5 & 5 & 3 & 3 & 1 & 3 & 1 & - & - & 27 \\
\hline Total & 11 & 28 & 23 & 25 & 32 & 32 & 30 & 34 & 46 & 25 & 286 \\
\hline
\end{tabular}

* Search covered to July, 2013 


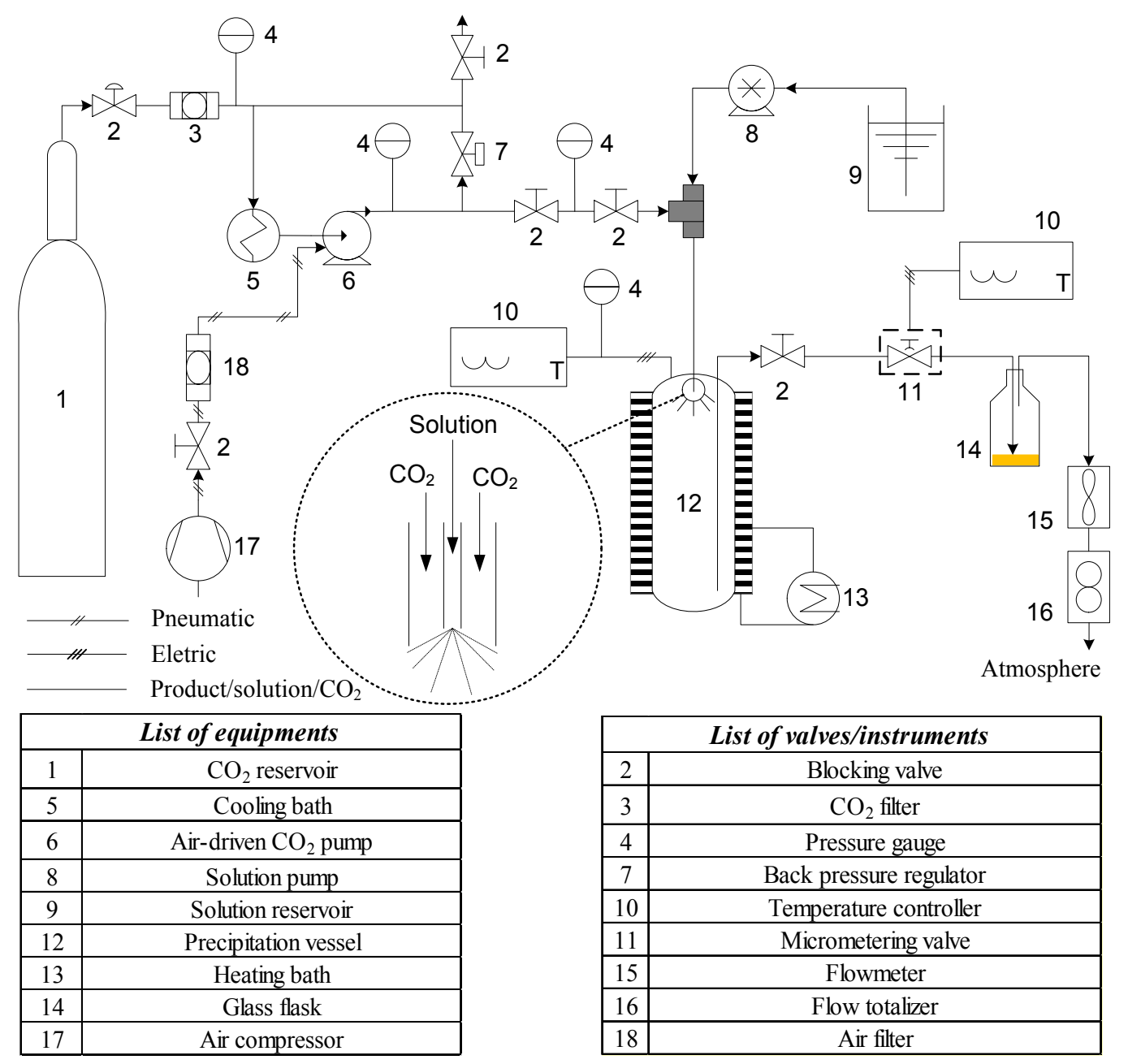

Scheme 1. Flowchart for an experimental micronization apparatus using supercritical $\mathrm{CO}_{2}$ (Adapted from Santos and Meireles [4])

Polymerization via the rapid expansion of supercritical solutions (RESS) is a promising technology that requires more detailed experiments. The trend is that the number of studies in LA on this subject will become more expansive and allow production of these devices on an industrial scale.

Another supercritical fluid application emerging in LA countries corresponds to the high-pressure treatment of lignocellulosic biomass called explosion with supercritical $\mathrm{CO}_{2}$ (ESC). This treatment improves the subsequent heavy metal-removal step. Copper adsorption experiments were performed on waste banana peels submitted to extraction and ESC. Integrating these processes had a more pronounced effect on the vegetable structure and retained the adsorption capacity [20].

In contrast, the number of publications discussing the thermodynamics \& fundamentals has decreased. From 1994-2003, 49 scientific documents (25\% of the total) published by researchers from LA related to this topic. Since 2004, only 27 documents (9\% of the total) were published on this topic. Documents classified as "thermodynamics \& fundamentals" cover research on thermodynamic parameters and properties [21], the determination of solubility for compound mixtures [22], thermodynamic modeling and simulation [23], [24] and phase equilibrium in supercritical conditions [25], [26].

The recent reduction in the percent of publications comprising this research topic in LA (25\% at 1994-2003; 9\% at 2004-2013) is justified for the following two reasons: (i) the emergence of new lines of research and (ii) the high availability of information from global scientific literature discussing such concepts, which hinders novel studies. Nevertheless, there is still much to explore in the food sector because the behavior of biological and nutraceutical substances in extraction systems is very complex.

Some research groups in LA, mostly located at Argentina, Brazil, Chile, Colombia and Mexico, are focusing their studies on emerging areas which involving supercritical fluids. For energy applications, the hydrolysis of sugar biomass and second generation ethanol production have been studied by several researchers [27-29].

In these fields, Pellegrini et al [30] simulated a cogeneration system for producing energy for sugarcane mills using supercritical steam (pressures up to $30 \mathrm{MPa}$ and temperatures up to $600^{\circ} \mathrm{C}$ ) and integrated biomass gasification cycles. The proposed system generated roughly three times the excess electricity relative to currently available condensation-extraction steam turbines $(\approx 2 \mathrm{MPa}$ and $300^{\circ} \mathrm{C}$ ). This thermal integration system reduced the 
steam consumption by $43 \%$.

Some authors simulated integrated processes for power generation and reported increased efficiency [30], [31]. These findings mean integrating processes to increase their energetic yields tends to be an industrially useful thermo-economic alternative.

Microbiological inactivations and reactions in supercritical media that may or may not be catalyzed by enzymes have also been researched more intensely in LA over the last few years [32-35]. Numerical data indicate there were 21 scientific works $(\approx 7 \%$ of the total) published in the Journals indexed by Web of Science and/or Scopus since 2004, whereas there were only 4 scientific works during 1994-2003 $(\approx 2 \%$ of the total).

In the same way, the use of supercritical fluids for analytical applications has progressed greatly over the world in recent years. In LA, papers discussing the development of an SFE method for determining pesticides in fruit and vegetables [36], enantioseparation of mitotane via supercritical fluid chromatography (SFC) [37], analysis of nitrosamines in sausages [38] and determination of hydrocarbons in petroleum products [39] were published.

Brazil ranks 11th in the world for publications on supercritical fluids. Approximately $3.1 \%$ of the worldwide publications in this field are from Brazil. Considering only Latin-American publications, the country has the highest contribution, with $59 \%$ of the total publications (Figure 1). The current research of the 5 major scientific countries in LA is shown in Table 2.
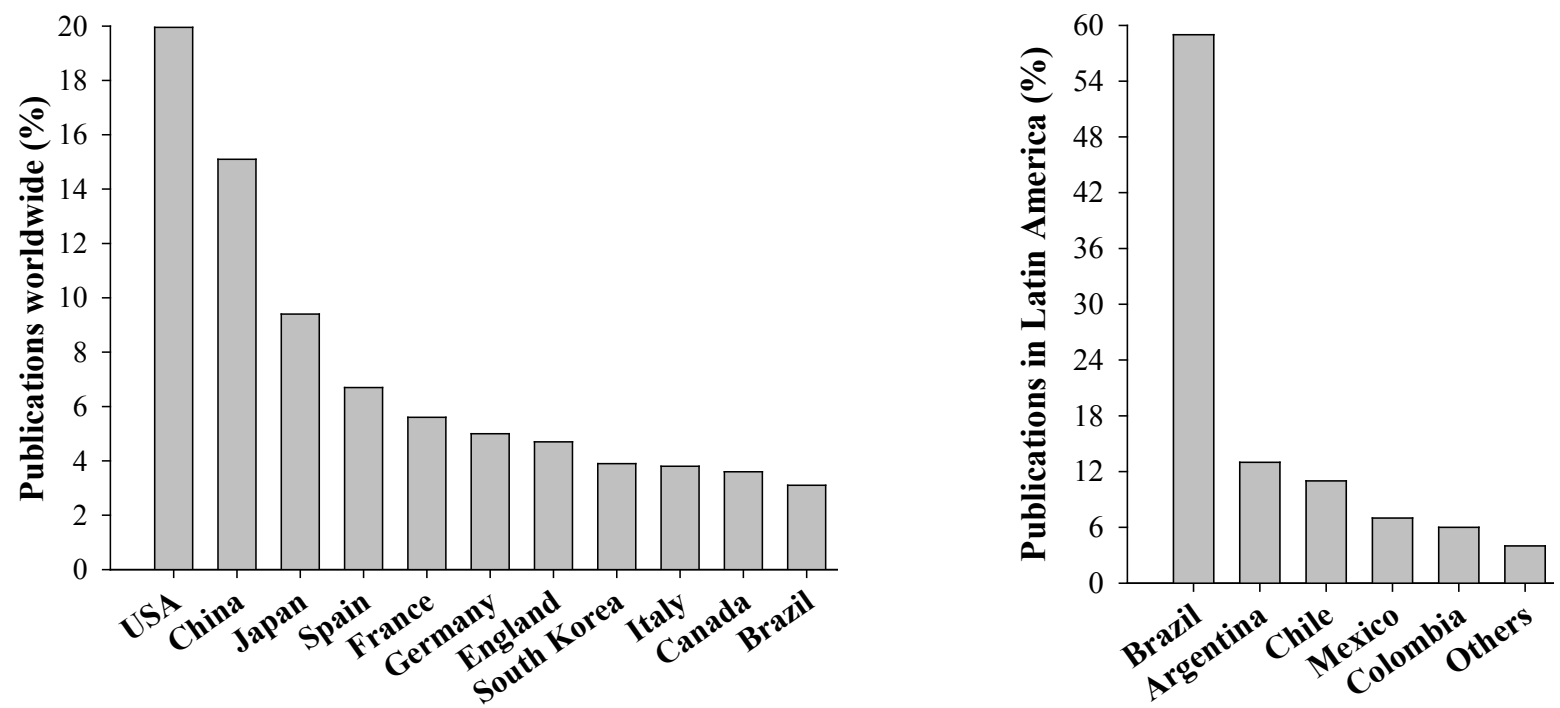

Figure 1. Contributions of the major scientific countries that have been researching supercritical fluids from 2004-2013

Table 2. Current research performed in LA countries

\begin{tabular}{|c|c|c|c|c|c|}
\hline Raw material & Methods & $\begin{array}{c}\text { Experimental } \\
\text { determinations }\end{array}$ & $\begin{array}{l}\text { Extracts/Products } \\
\text { characterization }\end{array}$ & $\begin{array}{c}\text { Theoretical } \\
\text { studies }\end{array}$ & Ref. \\
\hline Annatto (Bixa orellana L.) & SFE; SAS; RESS & PY; EE & SEM & - & [4] \\
\hline Grape (Vitis vinifera) & SFE & $\mathrm{X} 0$ & HPLC; AA; MIC & - & [40] \\
\hline Nut (Anacardium occidentale) & SFE & OEC & TLC & $\mathrm{MM} ; \mathrm{COM}$ & [41] \\
\hline Sage (Salvia officinalis) & SFF & OEC & GC-MS & PS & [42] \\
\hline Mushroom (Agaricus brasiliensis) & SFE & $\mathrm{X} 0$; IE; OEC & AA; MIC; AAc & - & [43] \\
\hline Boldo (Peumus boldus M.) & SFE & OEC & SEM & MM & [44] \\
\hline Jabuticaba (Myrciaria cauliflora) & PLE & $\mathrm{X} 0$; OEC & TMA; TPC & PS; COM; SU & [45] \\
\hline Guava (Psidium guajava) & SFE & $\mathrm{X} 0 ; \mathrm{IE} ; \mathrm{OEC}$ & TLC; GC-MS & MM & [46] \\
\hline Ginger (Zingiber officinale) & SFE & OEC & GC-FID; AAc & - & [47] \\
\hline Garlic (Allium sativum) & SFE & IE; OEC & Spectrophotometer & MM & [48] \\
\hline Mint (Mentha spicata L.) & SFE & $\mathrm{X} 0$; IE & AAc; GC-MS & - & [49] \\
\hline Buriti (Mauritia flexuosa M.) & SA & AK & SEM; GC-FID & MM & {$[50]$} \\
\hline Banana (Musa spp.) & ESC; SFE & $\mathrm{AK} ; \mathrm{AE}$ & SEM; DSC & MM & [20] \\
\hline
\end{tabular}

SFE: Supercritical fluid Extraction; SAS: Supercritical CO2 as Antisolvent; RESS: Rapid Expansion of Supercritical Solutions; PY: Precipitation Yield; EE: Encapsulation Efficiency; SEM: Scanning Electron Microscopy; X0: Global Extraction Yield; HPLC: High Performance Liquid Chromatography; AA: Antimicrobial Activity; MIC: Minimum Inhibition Concentration; OEC: Overall Extraction Curves; TLC: Thin Layer Chromatography; MM: Mathematical Modeling; COM: Cost of Manufacturing; SFF: Supercritical Fluid Fractionation; GC-MS: Gas Chromatograph - Mass Spectrometer; PS: Process Simulation; IE: Isotherms of Extraction; AAc: Antioxidant Activity; PLE: Pressurized Liquid Extraction; TMA: Total Monomeric Anthocyanin Content; TPC: Total Phenolic Compounds Content; SU: Scale up; GC-FID: Gas Chromatograph - Flame Ionization Detector; SA: Supercritical Adsorption; ESC: Explosion with Supercritical CO2; DSC: Differential Scanning Calorimetry; AK: Adsorption Kinetics; AE: Adsorption Equilibrium 


\section{Patent Survey}

A search of patents containing the term 'supercritical fluid*' in the Derwent Innovations Index (Web of Science database) returned 5,632 patents by inventors around the world. However, only 2 patents were addressed from one of the 33 countries in LA. Indeed, most patents are registered in local databases, as is the case in Brazil where patents are deposited at INPI (Brazilian National Institute of Industrial Property)
The 2 patents found in Web of Science were invented in Colombia. Invention WO2012066389 [51] is a novel process for producing aqueous suspensions of calcium salt micro- and nanoparticles smaller than $10 \mu \mathrm{m}$ using critical, subcritical and supercritical carbon dioxide. This property of the fluid increases the solubility of the calcium salt, which allows enriching nutritional, nutraceutical and pharmaceutical beverages with calcium salts.

Table 3. Summary of studies developed in Latin America from 2010-2012

\begin{tabular}{|c|c|c|c|c|}
\hline Country & Study group & Article title & Year & Ref. \\
\hline \multirow{15}{*}{ 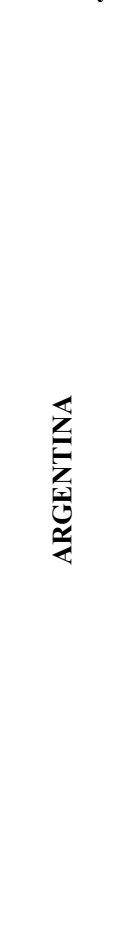 } & \multirow{2}{*}{$\begin{array}{l}\text { Analytical } \\
\text { applications }\end{array}$} & $\begin{array}{l}\text { Sorption and diffusion of compressed carbon dioxide in polycaprolactone for the } \\
\text { development of porous scaffolds }\end{array}$ & 2012 & {$[60]$} \\
\hline & & Proton transfer from 2-naphthol to aliphatic amines in supercritical $\mathrm{CO}_{2}$ & 2011 & [61] \\
\hline & Energy applications & Ketalization of glycerol to solketal in supercritical acetone & 2011 & [62] \\
\hline & \multirow{8}{*}{$\begin{array}{c}\text { Fundamental \& } \\
\text { thermodynamic } \\
\text { studies }\end{array}$} & $\begin{array}{l}\text { Fractionation of essential oils with biocidal activity using supercritical } \mathrm{CO}_{2} \text {-experiments and } \\
\text { modeling }\end{array}$ & 2011 & [63] \\
\hline & & $\begin{array}{l}\text { Critical effects on attractive solutes in binary liquid mixtures close to their consolute point: a } \\
\text { new experimental strategy }\end{array}$ & 2011 & {$[64]$} \\
\hline & & $\begin{array}{l}\text { AVA seismic reflectivity analysis in carbon dioxide accumulations: sensitivity to } \mathrm{CO}_{2} \text { phase } \\
\text { and saturation }\end{array}$ & 2011 & [65] \\
\hline & & $\begin{array}{l}\text { Computation of solid-fluid-fluid equilibria for binary asymmetric mixtures in wide ranges of } \\
\text { conditions }\end{array}$ & 2011 & [66] \\
\hline & & $\begin{array}{l}\text { Equation of state modeling of the phase equilibria of asymmetric } \mathrm{CO}_{2}+\mathrm{n} \text {-alkane binary } \\
\text { systems using mixing rules cubic with respect to mole fraction }\end{array}$ & 2010 & [67] \\
\hline & & $\begin{array}{l}\text { Near-critical and supercritical dilute solutions viewed from macroscopic and molecular-scale } \\
\text { perspectives }\end{array}$ & 2010 & [68] \\
\hline & & $\begin{array}{l}\text { Experimental cloud points for polybutadiene plus light solvent and polyethylene plus light } \\
\text { solvent systems at high pressure }\end{array}$ & 2010 & [69] \\
\hline & & Isochoric lines and determination of phase transitions in supercritical reactors & 2010 & [70] \\
\hline & \multirow{2}{*}{$\begin{array}{l}\text { Material and } \\
\text { micronization } \\
\text { applications }\end{array}$} & Precipitation and encapsulation of rosemary antioxidants by supercritical antisolvent process & 2012 & [71] \\
\hline & & $\begin{array}{l}\text { Supercritical } \mathrm{CO}_{2} \text { fractionation of rosemary ethanolic oleoresins as a method to improve } \\
\text { carnosic acid recovery }\end{array}$ & 2011 & [72] \\
\hline & $\begin{array}{c}\text { Reactions in } \\
\text { supercritical fluids }\end{array}$ & Grafting of styrene onto polyethylene in near critical media & 2012 & [73] \\
\hline & $\begin{array}{l}\text { Reviews and } \\
\text { perspectives }\end{array}$ & Optimizing design in open channel & 2010 & [74] \\
\hline \multirow{13}{*}{$\frac{\bar{N}}{\underline{\underline{N}}}$} & \multirow{6}{*}{$\begin{array}{l}\text { Analytical } \\
\text { applications }\end{array}$} & $\begin{array}{l}\text { Single laboratory validation of a SPE method for the determination of PAHs in edible oils by } \\
\text { GC-MS }\end{array}$ & 2012 & [75] \\
\hline & & $\begin{array}{l}\text { Supercritical adsorption of buriti oil (Mauritia flexuosa Mart.) in gamma-alumina: A } \\
\text { methodology for the enriching of anti-oxidants }\end{array}$ & 2012 & [76] \\
\hline & & Effects of supercritical carbon dioxide on waste banana peels for heavy metal removal & 2011 & [20] \\
\hline & & $\begin{array}{l}\text { SFE from Bidens pilosa Linne to obtain extracts rich in cytotoxic polyacetylenes with } \\
\text { antitumor activity }\end{array}$ & 2011 & [77] \\
\hline & & $\begin{array}{l}\text { Biological activities of Solanum paludosum Moric. extracts obtained by maceration and } \\
\text { supercritical fluid extraction }\end{array}$ & 2011 & [78] \\
\hline & & $\begin{array}{l}\text { Supercritical carbon dioxide selectivity to fractionate phenolic compounds from the dry } \\
\text { ethanolic extract of propolis }\end{array}$ & 2010 & [79] \\
\hline & \multirow{2}{*}{$\begin{array}{l}\text { Economic } \\
\text { applications }\end{array}$} & $\begin{array}{l}\text { Supercritical anti-solvent precipitation of carotenoid fraction from pink shrimp residue: } \\
\text { Effect of operational conditions on encapsulation efficiency }\end{array}$ & 2012 & [80] \\
\hline & & Manufacturing cost of supercritical-extracted oils and carotenoids from amazonian plants & 2010 & [81] \\
\hline & \multirow[t]{2}{*}{ Energy applications } & $\begin{array}{l}\text { Preliminary studies on advanced power generation based on combined cycle using a single } \\
\text { high-pressure fluidized bed boiler and consuming sugar-cane bagasse }\end{array}$ & 2012 & [31] \\
\hline & & Sustainable energy: A review of gasification technologies & 2012 & [82] \\
\hline & \multirow{3}{*}{ Extractionapplications } & $\begin{array}{l}\text { Radical-scavenging activity of extracts from Cordia verbenacea DC obtained by different } \\
\text { methods }\end{array}$ & 2011 & [83] \\
\hline & & $\begin{array}{l}\text { Supercritical extraction from vinification residues: Fatty acids, alpha-tocopherol, and } \\
\text { phenolic compounds in the oil seeds from different varieties of grape }\end{array}$ & 2012 & [84] \\
\hline & & Supercritical extraction of linseed oil: economical viability and modeling extraction curves & 2013 & [85] \\
\hline
\end{tabular}


Table 3. (Continued)

\begin{tabular}{|c|c|c|c|c|}
\hline Country & Study group & Article title & Year & Ref. \\
\hline \multirow{29}{*}{ 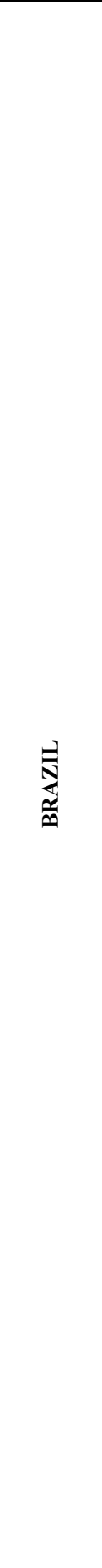 } & \multirow{29}{*}{ Extraction applications } & $\begin{array}{l}\text { Radical-scavenging activity of extracts from Cordia verbenacea DC obtained by different } \\
\text { methods }\end{array}$ & 2011 & [83] \\
\hline & & $\begin{array}{l}\text { Supercritical extraction from vinification residues: Fatty acids, alpha-tocopherol, and phenolic } \\
\text { compounds in the oil seeds from different varieties of grape }\end{array}$ & 2012 & [84] \\
\hline & & Supercritical extraction of linseed oil: economical viability and modeling extraction curves & 2013 & [85] \\
\hline & & $\begin{array}{l}\text { Extracts from the leaves of Piper piscatorum (Trel. Yunc.) obtained by supercritical extraction } \\
\text { of with } \mathrm{CO}_{2} \text {, employing ethanol and methanol as cosolvents }\end{array}$ & 2013 & {$[86]$} \\
\hline & & $\begin{array}{l}\text { Extraction from striped weakfish (Cynoscion striatus) wastes with pressurized } \mathrm{CO}_{2} \text { : global } \\
\text { yield, composition, kinetics and cost estimation }\end{array}$ & 2012 & [87] \\
\hline & & $\begin{array}{l}\text { Defatting of annatto seeds using supercritical carbon dioxide as a pretreatment for the } \\
\text { production of bixin: experimental, modeling and economic evaluation of the process }\end{array}$ & 2012 & [88] \\
\hline & & $\begin{array}{l}\text { Extraction of Mentha spicata } \mathrm{L} \text {. Volatile compounds: Evaluation of process parameters and } \\
\text { extract composition }\end{array}$ & 2012 & [49] \\
\hline & & $\begin{array}{l}\text { Supercritical fluid extraction from spent coffee grounds and coffee husks: Antioxidant activity } \\
\text { and effect of operational variables on extract composition }\end{array}$ & 2012 & [89] \\
\hline & & $\begin{array}{l}\text { HPLC analysis of supercritical carbon dioxide and compressed propane extracts from Piper } \\
\text { amalago L. with antileishmanial activity }\end{array}$ & 2012 & [90] \\
\hline & & Extraction, fatty acid profile and antioxidant activity of sesame extract (Sesamum Indicum L.) & 2012 & [91] \\
\hline & & $\begin{array}{l}\text { Characteristics of the extract of Litopenaeus vannamei shrimp obtained from the cephalothorax } \\
\text { using pressurized } \mathrm{CO}_{2}\end{array}$ & 2012 & [92] \\
\hline & & $\begin{array}{l}\text { HPLC analysis and antileishmanial activity of supercritical fluids extracts from Piper amalago } \\
\text { L }\end{array}$ & 2012 & [93] \\
\hline & & Supercritical fluid extraction of hernandulcin from Lippia dulcis Trev & 2012 & [94] \\
\hline & & $\begin{array}{l}\text { Extraction of Mucuna seed oil using supercritical carbon dioxide to increase the concentration } \\
\text { of L-Dopa in the defatted meal }\end{array}$ & 2012 & [95] \\
\hline & & Supercritical fluid extraction of Agaricus brasiliensis: Antioxidant and antimicrobial activities & 2012 & [96] \\
\hline & & $\begin{array}{l}\text { Supercritical fluid extraction from guava (Psidium guajava) leaves: global yield, composition } \\
\text { and kinetic data }\end{array}$ & 2012 & [46] \\
\hline & & $\begin{array}{l}\text { Effect of storage time and conditions on the diene valepotriates content of the extract of } \\
\text { valeriana glechomifolia obtained by supercritical carbon dioxide }\end{array}$ & 2012 & {$[97]$} \\
\hline & & $\begin{array}{l}\text { The antitumor activity of extracts from Cordia verbenacea DC obtained by supercritical fluid } \\
\text { extraction }\end{array}$ & 2012 & [98] \\
\hline & & $\begin{array}{l}\text { Supercritical fluid extraction of grape seed: Process scale-up, extract chemical composition } \\
\text { and economic evaluation }\end{array}$ & 2012 & [99] \\
\hline & & $\begin{array}{l}\text { Extraction of omega- } 3 \text { fatty acids and astaxanthin from Brazilian redspotted shrimp waste } \\
\text { using supercritical } \mathrm{CO}_{2}+\text { ethanol mixtures }\end{array}$ & 2012 & {$[100]$} \\
\hline & & Modeling oil extraction from green and roasted coffee by means of supercritical $\mathrm{CO}_{2}$ & 2012 & [101] \\
\hline & & Supercritical extraction of neolignans from Piper regnelli var. pallescens & 2012 & [102] \\
\hline & & $\begin{array}{l}\text { Supercritical extraction of phloroglucinol and benzophenone derivatives from Hypericum } \\
\text { carinatum: Quantification and mathematical modeling }\end{array}$ & 2011 & [103] \\
\hline & & Supercritical fluid extraction of volatile and non-volatile compounds from Schinus molle L & 2011 & [104] \\
\hline & & $\begin{array}{l}\text { Antifungal activity of supercritical fluid extract obtained from Calophyllum brasiliense } \\
\text { Cambess }\end{array}$ & 2011 & {$[105]$} \\
\hline & & $\begin{array}{l}\text { Identification of organic sulfur compounds in coal bitumen obtained by different extraction } \\
\text { techniques using comprehensive two-dimensional gas chromatography coupled to } \\
\text { time-of-flight mass spectrometric detection }\end{array}$ & 2011 & [106] \\
\hline & & $\begin{array}{l}\text { Supercritical fluid extracts from the Brazilian cherry (Eugenia uniflora L.): Relationship } \\
\text { between the extracted compounds and the characteristic flavour intensity of the fruit }\end{array}$ & 2011 & [107] \\
\hline & & $\begin{array}{l}\text { Pink shrimp ( } P . \text { brasiliensis and P. paulensis) residue: Influence of extraction method on } \\
\text { carotenoid concentration }\end{array}$ & 2011 & [108] \\
\hline & & $\begin{array}{l}\text { Extraction of sunflower (Heliantus annuus } \mathrm{L} \text {.) oil with supercritical } \mathrm{CO}_{2} \text { and subcritical } \\
\text { propane: Experimental and modeling }\end{array}$ & 2011 & [109] \\
\hline
\end{tabular}

The invention US2011237857 [52] is a process for the destruction of toxic residues via oxidation in the presence of water and oxygen developed in homogeneous supercritical condition of $374^{\circ} \mathrm{C}$ and $22 \mathrm{MPa}$. The proposed mobile processing unit is composed of a reactor, which includes pressurization, reaction, cooling, depressurization, and sampling zones for the destruction of toxic residues, such as polychloride biphenyls and pyridines.

\section{Cost of Manufacturing of Processes Involving Supercritical Fluids}

Mostly, supercritical technology processes present technical feasibility. Nonetheless, detailed studies about 
economic aspects are needed to transfer the knowledge acquired at laboratory/pilot scales to industrial scale. These studies are necessary to indicate (or not) the economic feasibility of the proposed system.

Based on the lack of detailed information, some LA studies have simulated the cost of manufacturing (COM) of extracts, mostly of SFE from vegetal raw materials. Cavalcanti et al [53] simulated the COM of jabuticaba extract obtained in extractors of several sizes. The lowest COM was about US\$ $10.00 / \mathrm{kg}$ in a system containing two 300 -liter extractors.
Veggi et al [54] compared the COM of jabuticaba extract obtained via PLE (Pressurized Liquid Extraction) to that of conventional extraction techniques for a system with two 300 liter extractors. The COM values differed as follows: US\$ $15.53 / \mathrm{kg}$ for PLE, US\$ $410.21 / \mathrm{kg}$ for ultrasound assisted extraction and US\$ $778.42 / \mathrm{kg}$ for a conventional Soxhlet extraction. Likewise, some scientists simulated the COM values for extracts from Amazonian plants obtained via SFE, such as buriti, pupunha, pressed palm fiber [55], annatto [56], pomegranate [57], grape [58] and sugarcane residues [59].

Table 3. (Continued)

\begin{tabular}{|c|c|c|c|c|}
\hline Country & Study group & Article title & Year & Ref. \\
\hline \multirow{30}{*}{ 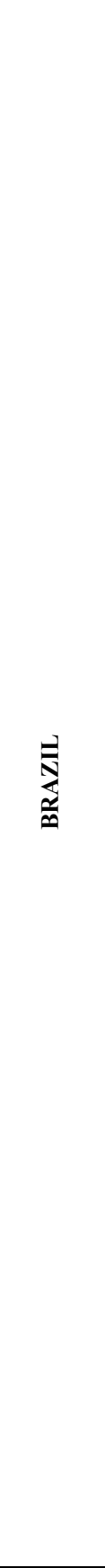 } & \multirow{18}{*}{ Extractionapplications } & Acute toxicity and anti-inflammatory effects of supercritical extracts of Ilex paraguariensis & 2011 & [110] \\
\hline & & $\begin{array}{l}\text { Extraction of canola seed (Brassica napus) oil using compressed propane and supercritical } \\
\text { carbon dioxide }\end{array}$ & 2011 & [111] \\
\hline & & Scale-up study of supercritical fluid extraction process for clove and sugarcane residue & 2011 & [59] \\
\hline & & $\begin{array}{l}\text { Chamomile extraction with supercritical carbon dioxide: Mathematical modeling and } \\
\text { optimization }\end{array}$ & 2011 & [112] \\
\hline & & $\begin{array}{l}\text { Supercritical } \mathrm{CO}_{2} \text { extraction of lipids and astaxanthin from Brazilian redspotted shrimp waste } \\
\text { (Farfantepenaeus paulensis) }\end{array}$ & 2011 & [113] \\
\hline & & $\begin{array}{l}\text { Proximate composition and extraction of carotenoids and lipids from Brazilian redspotted } \\
\text { shrimp waste (Farfantepenaeus paulensis) }\end{array}$ & 2011 & [114] \\
\hline & & $\begin{array}{l}\text { Extraction with supercritical fluid and comparison of chemical composition from adults and } \\
\text { young leaves of Zanthoxylum tingoassuiba }\end{array}$ & 2011 & [115] \\
\hline & & $\begin{array}{l}\text { Bioactive extracts of orange (Citrus sinensis L. Osbeck) pomace obtained by SFE and low } \\
\text { pressure techniques: Mathematical modeling and extract composition }\end{array}$ & 2010 & [116] \\
\hline & & $\begin{array}{l}\text { Supercritical fluid extraction and high performance liquid chromatographic determination of } \\
\text { benzopyrans and phloroglucinol derivative in Hypericum polyanthemum }\end{array}$ & 2010 & [117] \\
\hline & & Supercritical fluid extraction of alkaloids from Ilex paraguariensis St. Hil & 2010 & [118] \\
\hline & & $\begin{array}{l}\text { Extraction of sesame seed (Sesamun indicum L.) oil using compressed propane and } \\
\text { supercritical carbon dioxide }\end{array}$ & 2010 & [119] \\
\hline & & $\begin{array}{l}\text { Supercritical fluid extraction of lycopene from tomato juice and characterization of its } \\
\text { antioxidation activity }\end{array}$ & 2010 & {$[120]$} \\
\hline & & Recovery of gamma-oryzanol from rice bran oil byproduct using supercritical fluid extraction & 2010 & {$[121]$} \\
\hline & & $\begin{array}{l}\text { Supercritical fluid extraction of peach (Prunus persica) almond oil: Process yield and extract } \\
\text { composition }\end{array}$ & 2010 & [122] \\
\hline & & $\begin{array}{l}\text { A study of the methods of carotenoid extraction in carrots using supercritical fluid extraction } \\
\text { (SFE) and conventional methods }\end{array}$ & 2010 & [123] \\
\hline & & $\begin{array}{l}\text { Supercritical fluid extraction from dried banana peel (Musa spp., genomic group AAB): } \\
\text { Extraction yield, mathematical modeling, economic analysis and phase equilibria }\end{array}$ & 2010 & [124] \\
\hline & & $\begin{array}{l}\text { Characterization and functional properties of macela (Achyrocline satureioides) extracts } \\
\text { obtained by supercritical fluid extraction using mixtures of } \mathrm{CO}_{2} \text { plus ethanol }\end{array}$ & 2010 & [125] \\
\hline & & Extraction of the essential oil of abajeru (Chrysobalanus icaco) using supercritical $\mathrm{CO}_{2}$ & 2010 & {$[126]$} \\
\hline & \multirow{12}{*}{$\begin{array}{c}\text { Fundamental \& } \\
\text { thermodynamic } \\
\text { studies }\end{array}$} & Thermodynamic study of enantioseparation of mitotane by supercritical fluid chromatography & 2012 & [37] \\
\hline & & High-pressure phase behaviour of the system $\left(\mathrm{CO}_{2}+\mathrm{CI}\right.$ Disperse Orange 30 dye $)$ & 2012 & [127] \\
\hline & & $\begin{array}{l}\text { Selectivity of supercritical carbon dioxide in the fractionation of fish oil with a lower content } \\
\text { of EPA plus DHA }\end{array}$ & 2012 & [128] \\
\hline & & Safety study of an experimental apparatus for extraction with supercritical $\mathrm{CO}_{2}$ & 2012 & [129] \\
\hline & & Phase equilibrium data for the ternary system (propane plus chloroform plus oryzanol) & 2011 & {$[130]$} \\
\hline & & Supercritical technology as an alternative for biotechnological xylitol purification & 2011 & {$[131]$} \\
\hline & & Phase behavior of $\left(\mathrm{CO}_{2}+\right.$ methanol plus lauric acid $)$ system & 2011 & {$[132]$} \\
\hline & & High-pressure experimental data of $\mathrm{CO}_{2}+$ mitotane and $\mathrm{CO}_{2}+$ ethanol plus mitotane mixtures & 2011 & [133] \\
\hline & & $\begin{array}{l}\text { Thermodynamic modeling of liquid-fluid phase equilibrium in supercritical ethylene plus } \\
\text { copolymer plus co-solvent systems using the PC-SAFT equation of state }\end{array}$ & 2010 & [134] \\
\hline & & Phase behavior of binary systems of lactones in carbon dioxide & 2010 & {$[135]$} \\
\hline & & $\begin{array}{l}\text { Phase behavior of the ternary system poly(epsilon-caprolactone) plus carbon dioxide plus } \\
\text { dichloromethane }\end{array}$ & 2010 & {$[136]$} \\
\hline & & $\begin{array}{l}\text { Phase equilibrium data and thermodynamic modeling of the system propane plus NMP plus } \\
\text { methanol at high pressures }\end{array}$ & 2010 & {$[137]$} \\
\hline
\end{tabular}


Table 3. (Continued)

\begin{tabular}{|c|c|c|c|c|}
\hline Country & Study group & Article title & Year & Ref. \\
\hline \multirow{30}{*}{ 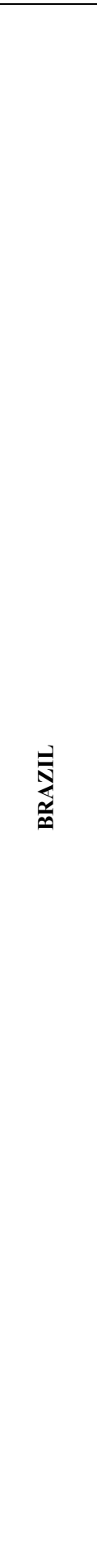 } & \multirow{4}{*}{$\begin{array}{l}\text { Fundamental \& } \\
\text { thermodynamic } \\
\text { studies }\end{array}$} & $\begin{array}{l}\text { Phase equilibrium measurements and modelling of ternary system (carbon dioxide plus } \\
\text { ethanol plus palmitic acid) }\end{array}$ & 2010 & [138] \\
\hline & & $\begin{array}{l}\text { Chemical characterization and phase behavior of grape seed oil in compressed carbon dioxide } \\
\text { and ethanol as co-solvent }\end{array}$ & 2010 & {$[26]$} \\
\hline & & High-pressure phase diagram of the drug mitotane in compressed and/or supercritical $\mathrm{CO}_{2}$ & 2010 & [139] \\
\hline & & $\begin{array}{l}\text { A first-principles simulation model for the thermo-hydraulic performance of fan supplied } \\
\text { tube-fin heat exchangers }\end{array}$ & 2010 & [140] \\
\hline & \multirow{9}{*}{$\begin{array}{l}\text { Material and } \\
\text { micronization } \\
\text { applications }\end{array}$} & Development of gas sensors coatings by polyaniline using pressurized fluid & 2012 & [141] \\
\hline & & Purification of single-wall carbon nanotubes by heat treatment and supercritical extraction & 2011 & [142] \\
\hline & & $\begin{array}{l}\mathrm{CO}_{2} \text { geological storage in saline aquifers: Parana basin caprock and reservoir chemical } \\
\text { reactivity }\end{array}$ & 2011 & [143] \\
\hline & & $\begin{array}{l}\text { Synthesis and characterization of } \mathrm{ZnO} / \mathrm{PET} \text { composite using supercritical carbon dioxide } \\
\text { impregnation technology }\end{array}$ & 2011 & [144] \\
\hline & & Economic viability of SFE from peach almond, spearmint and marigold & 2011 & [145] \\
\hline & & $\begin{array}{l}\text { In vitro release profiles of beta-carotene encapsulated in PHBV by means of supercritical } \\
\text { carbon dioxide micronization technique }\end{array}$ & 2011 & {$[13]$} \\
\hline & & $\begin{array}{l}\text { Impregnation of composite from polycarbonate }(\mathrm{PC}) \text { and silica gel (Si) films with } \\
\text { photochromic dye in supercritical fluid }\end{array}$ & 2010 & [146] \\
\hline & & $\begin{array}{l}\text { Precipitation and encapsulation of beta-carotene in PHBV using carbon dioxide as } \\
\text { anti-solvent }\end{array}$ & 2010 & {$[12]$} \\
\hline & & Gas sensors development using supercritical fluid technology to detect the ripeness of bananas & 2010 & {$[19]$} \\
\hline & \multirow{3}{*}{$\begin{array}{l}\text { Petroleum } \\
\text { applications }\end{array}$} & Mesophase evolution in heat-treated solid petroleum pitches & 2012 & [147] \\
\hline & & $\begin{array}{l}\text { Comparison of residual oil saturation for water and supercritical } \mathrm{CO}_{2} \text { flooding in a long core, } \\
\text { with live oil at reservoir conditions }\end{array}$ & 2011 & [148] \\
\hline & & Methods for the determination of conjugated dienes in petroleum products: a review & 2010 & [149] \\
\hline & \multirow{11}{*}{$\begin{array}{c}\text { Reactions in } \\
\text { supercritical fluids }\end{array}$} & $\begin{array}{l}\text { Biocomposites based on cellulose acetate and short curaua fibers treated with supercritical } \\
\mathrm{CO}_{2}\end{array}$ & 2012 & [150] \\
\hline & & Enzymatic synthesis of galactooligosaccharides using pressurized fluids as reaction medium & 2012 & {$[34]$} \\
\hline & & $\begin{array}{l}\text { Assessment of carotenoids recovery through cell rupture of Sporidiobolus salmonicolor CBS } \\
2636 \text { using compressed fluids }\end{array}$ & 2012 & [151] \\
\hline & & $\begin{array}{l}\text { Effect of compressed fluids treatment on the activity of inulinase from Kluyveromyces } \\
\text { marxianus NRRL Y-7571 immobilized in montmorillonite }\end{array}$ & 2011 & [152] \\
\hline & & $\begin{array}{l}\text { Effect of compressed fluids treatment on the activity, stability and enzymatic reaction } \\
\text { performance of beta-galactosidase }\end{array}$ & 2011 & [153] \\
\hline & & $\begin{array}{l}\text { Optimization of laccase catalyzed degradation of reactive textile dyes in supercritical carbon } \\
\text { dioxide medium by response surface methodology }\end{array}$ & 2010 & [154] \\
\hline & & $\begin{array}{l}\text { Compressed propane as a new and fast method of pre-purification of radish (Raphanus sativus } \\
\text { L.) peroxidase }\end{array}$ & 2010 & [155] \\
\hline & & Effect of treatment with compressed propane on lipases hydrolytic activity & 2010 & [156] \\
\hline & & Branched polyethylenes fractionated in supercritical propane & 2010 & [157] \\
\hline & & Lipase from Rhizomucor miehei as a biocatalyst in fats and oils modification & 2010 & [158] \\
\hline & & Lipase from Rhizomисоr miehei as an industrial biocatalyst in chemical process & 2010 & [159] \\
\hline & \multirow{3}{*}{$\begin{array}{l}\text { Reviews and } \\
\text { perspectives }\end{array}$} & Technological aspects of beta-carotene production & 2011 & [160] \\
\hline & & $\begin{array}{l}\text { Occurrence and chemical speciation analysis of organotin compounds in the environment: A } \\
\text { review }\end{array}$ & 2010 & [161] \\
\hline & & $\begin{array}{l}\text { Supercritical fluid extraction of bioactive compounds: Fundamentals, applications and } \\
\text { economic perspectives }\end{array}$ & 2010 & [162] \\
\hline
\end{tabular}


Table 3. (Continued)

\begin{tabular}{|c|c|c|c|c|}
\hline Country & Study group & Article title & Year & Ref. \\
\hline \multirow{19}{*}{ 䍖 } & $\begin{array}{c}\text { Analytical } \\
\text { applications }\end{array}$ & $\begin{array}{l}\text { A protocol for evaluating the safety of herbal preparations in a rat model: the case of a } \\
\text { supercritical fluid extract of Saw Palmetto }\end{array}$ & 2010 & [163] \\
\hline & \multirow{6}{*}{$\begin{array}{l}\text { Extraction } \\
\text { applications }\end{array}$} & A polyphenol extract of tara pods (Caesalpinia spinosa) as a potential antioxidant in oils & 2012 & [164] \\
\hline & & Extraction of oil and minor lipids from cold-press rapeseed cake with supercritical $\mathrm{CO}_{2}$ & 2012 & [165] \\
\hline & & $\begin{array}{l}\text { Effect of boldo (Peumus boldus M.) pretreatment on kinetics of supercritical } \mathrm{CO}_{2} \text { extraction } \\
\text { of essential oil }\end{array}$ & 2012 & [166] \\
\hline & & $\begin{array}{l}\text { Mass transfer and equilibrium parameters on high-pressure } \mathrm{CO}_{2} \text { extraction of plant essential } \\
\text { oils }\end{array}$ & 2011 & {$[167]$} \\
\hline & & $\begin{array}{l}\text { Oxidative stability of oils containing olive leaf extracts obtained by pressure, supercritical and } \\
\text { solvent-extraction }\end{array}$ & 2011 & {$[168]$} \\
\hline & & $\begin{array}{l}\text { Extraction of antioxidants from several berries pressing wastes using conventional and } \\
\text { supercritical solvents }\end{array}$ & 2010 & [169] \\
\hline & \multirow{11}{*}{$\begin{array}{l}\text { Fundamental \& } \\
\text { thermodynamic } \\
\text { studies }\end{array}$} & A refined equation for predicting the solubility of vegetable oils in high-pressure $\mathrm{CO}_{2}$ & 2012 & {$[170]$} \\
\hline & & $\begin{array}{l}\text { Free solute content and solute-matrix interactions affect apparent solubility and apparent } \\
\text { solute content in supercritical } \mathrm{CO}_{2} \text { extractions. a hypothesis paper }\end{array}$ & 2012 & [171] \\
\hline & & Supercritical $\mathrm{CO}_{2}$ extraction of allicin from garlic flakes: Screening and kinetic studies & 2012 & {$[48]$} \\
\hline & & Molar isopycnicity in heterogeneous binary mixtures & 2012 & [172] \\
\hline & & $\begin{array}{l}\text { Optimization of a cubic equation of state and van der Waals mixing rules for modeling the } \\
\text { phase behavior of complex mixtures }\end{array}$ & 2012 & [173] \\
\hline & & $\begin{array}{l}\text { Stevia rebaudiana Bertoni, source of a high-potency natural sweetener: A comprehensive } \\
\text { review on the biochemical, nutritional and functional aspects }\end{array}$ & 2012 & {$[174]$} \\
\hline & & Solubility of beta-carotene in ethanol- and triolein-modified $\mathrm{CO}_{2}$ & 2011 & {$[175]$} \\
\hline & & Simulation of a supercritical carbon dioxide extraction plant with three extraction vessels & 2011 & {$[176]$} \\
\hline & & $\begin{array}{l}\text { Solubility of nutraceutical carotenoid compounds in pure supercritical } \mathrm{CO}_{2} \text { and modified with } \\
\text { triolein or ethanol }\end{array}$ & 2010 & {$[22]$} \\
\hline & & $\begin{array}{l}\text { Solubilities in supercritical carbon dioxide of } \\
\text { (2E,6E)-3,7,11-Trimethyldodeca-2,6,10-trien-1-ol (Farnesol) and } \\
\text { (2S)-5,7-Dihydroxy-2-(4-hydroxyphenyl)chroman-4-one (Naringenin) }\end{array}$ & 2010 & {$[177]$} \\
\hline & & $\begin{array}{l}\text { Data analysis, modeling and thermodynamic consistency of } \mathrm{CO}_{2}+\text { beta-carotene high } \\
\text { pressure mixtures }\end{array}$ & 2010 & [178] \\
\hline & $\begin{array}{c}\text { Reactions in } \\
\text { supercritical fluids }\end{array}$ & Recent trends in biocatalysis engineering & 2012 & {$[179]$} \\
\hline \multirow{12}{*}{ 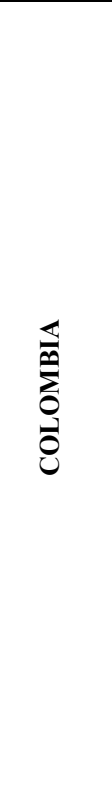 } & \multirow{10}{*}{$\begin{array}{l}\text { Extraction } \\
\text { applications }\end{array}$} & $\begin{array}{l}\text { Extraction of phenolic fraction from guava seeds (Psidium guajava L.) using supercritical } \\
\text { carbon dioxide and co-solvents }\end{array}$ & 2010 & {$[180]$} \\
\hline & & $\begin{array}{l}\text { Extraction of pesticides from soil using supercritical carbon dioxide added with methanol as } \\
\text { co-solvent }\end{array}$ & 2012 & {$[181]$} \\
\hline & & $\begin{array}{l}\text { Design and analysis of antioxidant compounds from Andes Berry fruits ( } R u b u s \text { glaucus } \\
\text { Benth) using an enhanced-fluidity liquid extraction process with } \mathrm{CO}_{2} \text { and ethanol }\end{array}$ & 2012 & {$[182]$} \\
\hline & & Extraction of oil from chia seeds with supercritical $\mathrm{CO}_{2}$ & 2011 & [183] \\
\hline & & $\begin{array}{l}\text { Guava (Psidium guajava L.) seed oil obtained with a homemade supercritical fluid extraction } \\
\text { system using supercritical } \mathrm{CO}_{2} \text { and co-solvent }\end{array}$ & 2011 & [184] \\
\hline & & $\begin{array}{l}\text { Lippia origanoides chemotype differentiation based on essential oil GC-MS and principal } \\
\text { component analysis }\end{array}$ & 2011 & [185] \\
\hline & & $\begin{array}{l}\text { Integrated utilization of guava (Psidium guajava 1.): antioxidant activity of phenolic extracts } \\
\text { obtained from guava seeds with supercritical } \mathrm{CO}_{2} \text {-ethanol }\end{array}$ & 2011 & [186] \\
\hline & & $\begin{array}{l}\text { Extraction of phenolic fraction from guava seeds (Psidium guajava L.) using supercritical } \\
\text { carbon dioxide and co-solvents }\end{array}$ & 2010 & {$[180]$} \\
\hline & & Separation of fractions from vacuum residue by supercritical extraction & 2010 & [187] \\
\hline & & $\begin{array}{l}\text { Reacting flow simulations of supercritical water oxidation of PCB-contaminated transformer } \\
\text { oil in a pilot plant reactor }\end{array}$ & 2011 & {$[188]$} \\
\hline & \multirow{2}{*}{$\begin{array}{l}\text { Reactions in } \\
\text { supercritical fluids }\end{array}$} & $\begin{array}{l}\text { Biodiesel fuels through a continuous flow process of chicken fat supercritical } \\
\text { transesterification }\end{array}$ & 2010 & [189] \\
\hline & & On the center of mass velocity in molecular dynamics simulations & 2012 & [190] \\
\hline
\end{tabular}


Table 3. (Continued)

\begin{tabular}{|c|c|c|c|c|}
\hline Country & Study group & Article title & Year & Ref. \\
\hline \multirow{11}{*}{ 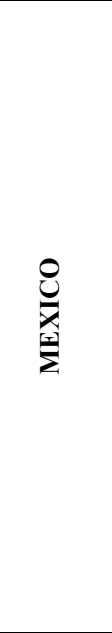 } & \multirow{6}{*}{$\begin{array}{l}\text { Fundamental \& } \\
\text { thermodynamic } \\
\text { studies }\end{array}$} & Effect of a temperature gradient on ellipsometry measurements in supercritical $\mathrm{CO}_{2}$ & 2012 & [191] \\
\hline & & $\begin{array}{l}\text { Correlation and prediction of fluid-fluid equilibria of carbon dioxide-aromatics and carbon } \\
\text { dioxide-dichlorobenzoates binary mixtures }\end{array}$ & 2011 & [192] \\
\hline & & Solubility of mesquite gum in supercritical carbon dioxide & 2011 & [193] \\
\hline & & New apparatus for solubility measurements of solids in carbon dioxide & 2011 & [194] \\
\hline & & Loci of extrema of thermodynamic response functions for the Lennard-Jones fluid & 2011 & [195] \\
\hline & & $\begin{array}{l}\text { Solubility and density measurements of palmitic acid in supercritical carbon dioxide plus } \\
\text { alcohol mixtures }\end{array}$ & 2010 & [196] \\
\hline & \multirow{2}{*}{$\begin{array}{l}\text { Material and } \\
\text { micronization } \\
\text { applications }\end{array}$} & $\begin{array}{l}\text { Microencapsulation of Coenzyme Q(10) in Poly(ethylene glycol) and Poly(lactic acid) with } \\
\text { Supercritical Carbon Dioxide }\end{array}$ & 2012 & [197] \\
\hline & & Hydrothermal synthesis of monodisperse single-crystalline alpha-quartz nanospheres & 2011 & [198] \\
\hline & \multirow{2}{*}{$\begin{array}{l}\text { Petroleum } \\
\text { applications }\end{array}$} & $\begin{array}{l}\text { Removal of polycyclic aromatic hydrocarbons from soil: A comparison between bioremoval } \\
\text { and supercritical fluids extraction }\end{array}$ & 2012 & [199] \\
\hline & & $\begin{array}{l}\text { Remediation of soils contaminated with total petroleum hydrocarbons and polycyclic } \\
\text { aromatic hydrocarbons: extraction with supercritical ethane }\end{array}$ & 2010 & {$[200]$} \\
\hline & $\begin{array}{l}\text { Reactions in } \\
\text { supercritical fluids }\end{array}$ & $\begin{array}{l}\text { Lipase-catalyzed syntheses of linear and hyperbranched polyesters using compressed fluids as } \\
\text { solvent media }\end{array}$ & 2010 & [201] \\
\hline
\end{tabular}

\section{Current Studies Performed in Latin America}

This section shows the studies that are currently being developed in LA. To facilitate visualization, Table 3 is arranged by study group for each major scientific country.

\section{Concluding Remarks}

The application of supercritical fluids to several processes, including emerging areas, is favorable for inclusion into technological plants in LA to obtain high value materials. Research and development of practical knowledge by universities and research centers in LA contribute to implementing supercritical technologies at the industrial scale. The large biodiversity of raw materials in these countries is a key factor for these future trends.

\section{ACKNOWLEDGMENTS}

Moyses N. Moraes thanks CAPES and Giovani L. Zabot thanks FAPESP (2011/23665-2) for their Ph.D. assistantships. M. A. A. Meireles acknowledges the productivity grant (301301/2010-7) from CNPq. The authors acknowledge the financial support of CAPES, CNPq and FAPESP.

\section{REFERENCES}

[1] J. M. del Valle, J. C. de la Fuente, D. A. Cardarelli, "Contributions to supercritical extraction of vegetable substrates in Latin America", J Food Eng, vol.67, no.1-2, pp.35-57, 2005.

[2] G. Crespi, P. Zuniga, "Innovation and productivity: Evidence from six latin american countries", World Dev, vol.40, no.2, pp.273-290, 2012.

[3] P. Zacchi, A. Pietsch, S. Voges, A. Ambrogi, R. Eggers, P. Jaeger, "Concepts of phase separation in supercritical processing", Chem. Eng. Process., vol.45, no.9, pp.728-733, 2006.

[4] D. T. Santos, M. A. A. Meireles, "Micronization and encapsulation of functional pigments using supercritical carbon dioxide", J Food Process Eng, vol.36, no.1, pp.36-49, 2013.

[5] P. T. V. Rosa, M. A. A. Meireles, "Supercritical technology in Brazil: system investigated (1994-2003)", J. Supercrit. Fluids, vol.34, no.2, pp.109-117, 2005.

[6] D. T. Santos, A. Martin, M. A. A. Meireles, M. J. Cocero, "Production of stabilized sub-micrometric particles of carotenoids using supercritical fluid extraction of emulsions", J. Supercrit. Fluids, vol.61, pp.167-174, 2012.

[7] M. L. Corazza, L. Cardozo Filho, C. Dariva, "Modeling and simulation of rapid expansion of supercritical solutions", Braz J Chem Eng, vol.23, no.3, pp.417-425, 2006.

[8] E. Franceschi, A. M. De Cesaro, M. Feiten, S. R. S. Ferreira, C. Dariva, M. H. Kunita, A. F. Rubira, E. C. Muniz, M. L. Corazza, J. V. Oliveira, "Precipitation of beta-carotene and PHBV and co-precipitation from SEDS technique using supercritical $\mathrm{CO}_{2}$ ", J. Supercrit. Fluids, vol.47, no.2, pp.259-269, 2008.

[9] E. Franceschi, M. H. Kunita, M. V. Tres, A. F. Rubira, E. C. Muniz, M. L. Corazza, C. Dariva, S. R. S. Ferreira, J. V. Oliveira, "Phase behavior and process parameters effects on the characteristics of precipitated theophylline using carbon dioxide as antisolvent", J. Supercrit. Fluids, vol.44, no.1, pp.8-20, 2008.

[10] E. Franceschi, A. M. De Cesaro, S. R. S. Ferreira, J. Vladimir Oliveira, "Precipitation of $\beta$-carotene microparticles from SEDS technique using supercritical $\mathrm{CO}_{2}$ ", J Food Eng, vol.95, no.4, pp.656-663, 2009.

[11] E. Franceschi, A. de Cezaro, S. R. S. Ferreira, M. H. Kunita, E. C. Muniz, A. F. Rubira, J. Vladimir Oliveira, "Co-precipitation of beta-carotene and bio-polymer using 
supercritical carbon dioxide as antisolvent", Open Chem Eng J, vol.4, no.1, pp.11-20, 2010.

[12] W. L. Priamo, A. M. de Cezaro, S. R. S. Ferreira, J. Vladimir Oliveira, "Precipitation and encapsulation of beta-carotene in PHBV using carbon dioxide as anti-solvent", J. Supercrit. Fluids, vol.54, no.1, pp.103-109, 2010.

[13] W. L. Priamo, A. M. de Cezaro, S. C. Benetti, J. V. Oliveira, S. R. S. Ferreira, "In vitro release profiles of beta-carotene encapsulated in PHBV by means of supercritical carbon dioxide micronization technique", J. Supercrit. Fluids, vol.56, no.2, pp.137-143, 2011

[14] D. T. Santos, J. Q. Albarelli, M. M. Beppu, M. A. A. Meireles, "Stabilization of anthocyanin extract from jabuticaba skins by encapsulation using supercritical $\mathrm{CO}_{2}$ as solvent", Food Res Int, vol.50, no.2, pp.617-624, 2013.

[15] E. T. Tenorio-Neto, E. L. Silva, T. S. P. Cellet, E. P. Silva, E. Franceschi, L. C. Filho, A. F. Rubira, M. H. Kunita, "Coprecipitation of safrole oxide with Poly (3-hydroxybutyrate-co-3-hydroxyvalerate) in supercritical carbon dioxide", J. Braz. Chem. Soc., vol.24, no.2, pp.327-335, 2013.

[16] C. Steffens, A. Manzoli, E. Francheschi, M. L. Corazza, F. C. Corazza, J. V. Oliveira, P. S. P. Herrmann, "Low-cost sensors developed on paper by line patterning with graphite and polyaniline coating with supercritical $\mathrm{CO}_{2}$ ", Synth. Met., vol.159, no.21-22, pp.2329-2332, 2009.

[17] C. Steffens, M. L. Corazza, E. Franceschi, F. Castilhos, P. S. P. Herrmann, J. V. Oliveira, "Development of gas sensors coatings by polyaniline using pressurized fluid", Sensor Actuat B-Chem, vol.171, pp.627-633, 2012.

[18] J. L. Fulton, G. S. Deverman, C. R. Yonker, J. W. Grate, J. De Young, J. B. McClain, "Thin fluoropolymer films and nanoparticle coatings from the rapid expansion of supercritical carbon dioxide solutions with electrostatic collection", Polymer, vol.44, no.13, pp.3627-3632, 2003.

[19] C. Steffens, E. Franceschi, F. C. Corazza, P. S. P. Herrmann, Jr., J. V. Oliveira, "Gas sensors development using supercritical fluid technology to detect the ripeness of bananas", J Food Eng, vol.101, no.4, pp.365-369, 2010.

[20] J. Q. Albarelli, R. B. Rabelo, D. T. Santos, M. M. Beppu, M. A. A. Meireles, "Effects of supercritical carbon dioxide on waste banana peels for heavy metal removal", J. Supercrit. Fluids, vol.58, no.3, pp.343-351, 2011.

[21] C. M. Silva, C. A. Filho, M. B. Quadri, E. A. Macedo, "Binary diffusion coefficients of alpha-pinene and beta-pinene in supercritical carbon dioxide", J. Supercrit. Fluids, vol.32, no.1-3, pp.167-175, 2004.

[22] K. A. Araus, R. I. Canales, P. S. Robert, J. M. del Valle, J. C. de la Fuente, "Solubility of nutraceutical carotenoid compounds in pure supercritical $\mathrm{CO}_{2}$ and modified with triolein or ethanol", J. Biotechnol., vol.150, pp.S331-S332, 2010.

[23] S. de Melo, R. de Melo, G. M. N. Costa, T. L. M. Alves, "Solubility of L-Dopa in supercritical carbon dioxide: prediction using a cubic equation of state", J. Supercrit. Fluids, vol.34, no.2, pp.231-236, 2005.

[24] F. W. Favero, M. S. Skaf, "Solvation of purine alkaloids in supercritical $\mathrm{CO}_{2}$ by molecular dynamics simulations", J.
Supercrit. Fluids, vol.34, no.2, pp.237-241, 2005.

[25] T. M. Takeuchi, P. F. Leal, R. Favareto, L. Cardozo-Filho, M. L. Corazza, P. T. V. Rosa, M. A. A. Meireles, "Study of the phase equilibrium formed inside the flash tank used at the separation step of a supercritical fluid extraction unit", J. Supercrit. Fluids, vol.43, no.3, pp.447-459, 2008.

[26] I. Dalmolin, M. A. Mazutti, E. A. C. Batista, M. A. A. Meireles, J. V. Oliveira, "Chemical characterization and phase behaviour of grape seed oil in compressed carbon dioxide and ethanol as co-solvent", J. Chem. Thermodyn., vol.42, no.6, pp.797-801, 2010.

[27] T. Benazzi, S. Calgaroto, V. Astolfi, C. Dalla Rosa, J. V. Oliveira, M. A. Mazutti, "Pretreatment of sugarcane bagasse using supercritical carbon dioxide combined with ultrasound to improve the enzymatic hydrolysis", Enzyme Microb. Technol., vol.52, no.4-5, pp.247-250, 2013.

[28] S. R. M. Moreschi, J. C. Leal, M. E. M. Braga, M. A. A. Meireles, "Ginger and turmeric starches hydrolysis using subcritical water $+\mathrm{CO}_{2}$ : The effect of the SFE pre-treatment", Braz J Chem Eng, vol.23, no.2, pp.235-242, 2006.

[29] J. Q. Albarelli, A. V. Ensinas, M. A. Silva, 2012, Combined first and second generation ethanol production: Analysis of supercritical hydrolysis, Proc. 15th International Conference on Process Integration, Modelling and Optimisation for Energy Saving and Pollution Reduction,

[30] L. F. Pellegrini, S. de Oliveira Junior, J. Carlos Burbano, "Supercritical steam cycles and biomass integrated gasification combined cycles for sugarcane mills", Energy, vol.36, no.1, pp.708-708, 2011.

[31] M. L. de Souza-Santos, J. V. Chavez, "Preliminary studies on advanced power generation based on combined cycle using a single high-pressure fluidized bed boiler and consuming sugar-cane bagasse", Fuel, vol.95, no.1, pp.221-225, 2012.

[32] D. Soares, L. A. Lerin, R. L. Cansian, J. V. Oliveira, M. A. Mazutti, "Inactivation of Listeria monocytogenes using supercritical carbon dioxide in a high-pressure variable-volume reactor", Food Control, vol.31, no.2, pp.514-518, 2013.

[33] J. M. Silva, A. A. Rigo, I. A. Dalmolin, I. Debien, R. L. Cansian, J. V. Oliveira, M. A. Mazutti, "Effect of pressure, depressurization rate and pressure cycling on the inactivation of Escherichia coli by supercritical carbon dioxide", Food Control, vol.29, no.1, pp.76-81, 2013.

[34] A. P. Manera, G. L. Zabot, J. Vladimir Oliveira, D. de Oliveira, M. A. Mazutti, S. J. Kalil, H. Treichel, F. Maugeri Filho, "Enzymatic synthesis of galactooligosaccharides using pressurised fluids as reaction medium", Food Chem., vol.133, no.4, pp.1408-1413, 2012.

[35] S. R. Comim Rosso, E. Bianchin, D. de Oliveira, J. V. Oliveira, S. R. S. Ferreira, 2012, Enzymatic synthesis of poly ( $\varepsilon$-caprolactone) in supercritical carbon dioxide medium by means of a variable-volume view reactor, Proc. 10th International Symposyum on Supercritical Fluids, San Francisco, USA.

[36] S. R. Rissato, M. S. Galhiane, A. G. De Souza, B. M. Apon, "Development of a supercritical fluid extraction method for simultaneous determination of organophosphorus, organohalogen, organonitrogen and pyretroids pesticides in 
fruit and vegetables and its comparison with a conventional method by GC-ECD and GC-MS", J. Braz. Chem. Soc., vol.16, no.5, pp.1038-1047, 2005.

[37] F. Antelo, C. C. Santana, T. L. Moitinho Alves, A. G. Barreto, Jr., "Thermodynamic study of enantioseparation of mitotane by supercritical fluid chromatography", Sep. Sci. Technol., vol.47, no.4, pp.636-640, 2012.

[38] P. J. Sanches, A. Rios, M. Valcarcel, M. I. S. Melecchi, E. B. Caramao, "Method of determination of nitrosamines in sausages by $\mathrm{CO}_{2}$ supercritical fluid extraction (SFE) and micellar electrokinetic chromatography (MEKC)", J. Agric. Food Chem., vol.55, no.3, pp.603-607, 2007.

[39] F. C. Albuquerque, "Determination of conjugated dienes in petroleum products by supercritical fluid chromatography and ultraviolet detection", J. Sep. Sci., vol.26, no.15-16, pp.1403-1406, 2003

[40] D. A. Oliveira, A. A. Salvador, A. Smania, E. F. A. Smania, M. Maraschin, S. R. S. Ferreira, "Antimicrobial activity and composition profile of grape (Vitis vinifera) pomace extracts obtained by supercritical fluids", J. Biotechnol., vol.164, no.3, pp.423-432, 2013.

[41] N. Leitao, G. H. C. Prado, P. C. Veggi, M. A. A. Meireles, C. G. Pereira, "Anacardium occidentale L. leaves extraction via SFE: Global yields, extraction kinetics, mathematical modeling and economic evaluation", J. Supercrit. Fluids, vol.78, pp.114-123, 2013.

[42] N. Ganan, E. A. Brignole, "Supercritical carbon dioxide fractionation of T. minuta and S. officinalis essential oils: Experiments and process analysis", J. Supercrit. Fluids, vol.78, pp.12-20, 2013.

[43] S. Mazzutti, S. R. S. Ferreira, C. A. S. Riehl, A. Smania Jr, F. A. Smania, J. Martínez, "Supercritical fluid extraction of Agaricus brasiliensis: Antioxidant and antimicrobial activities", J. Supercrit. Fluids, vol.70, pp.48-56, 2012.

[44] E. Uquiche, E. Huerta, A. Sandoval, J. M. del Valle, "Effect of boldo (Peumus boldus M.) pretreatment on kinetics of supercritical $\mathrm{CO}_{2}$ extraction of essential oil", J Food Eng, vol.109, no.2, pp.230-237, 2012.

[45] D. T. Santos, P. C. Veggi, M. A. A. Meireles, "Optimization and economic evaluation of pressurized liquid extraction of phenolic compounds from jabuticaba skins", J Food Eng, vol.108, no.3, pp.444-452, 2012.

[46] P. M. Moura, G. H. C. Prado, M. A. A. Meireles, C. G. Pereira, "Supercritical fluid extraction from guava (Psidium guajava) leaves: global yield, composition and kinetic data", J. Supercrit. Fluids, vol.62, pp.116-122, 2012.

[47] M. C. Mesomo, A. D. Scheer, E. Perez, P. M. Ndiaye, M. L. Corazza, "Ginger (Zingiber officinale R.) extracts obtained using supercritical $\mathrm{CO}_{2}$ and compressed propane: kinetics and antioxidant activity evaluation", J. Supercrit. Fluids, vol.71, pp.102-109, 2012.

[48] J. M. del Valle, V. Glatzel, J. L. Martinez, "Supercritical $\mathrm{CO}_{2}$ extraction of allicin from garlic flakes: Screening and kinetic studies", Food Res Int, vol.45, no.1, pp.216-224, 2012.

[49] P. P. Almeida, N. Mezzomo, S. R. S. Ferreira, "Extraction of Mentha spicata L. volatile compounds: Evaluation of process parameters and extract composition", Food
Bioprocess Tech, vol.5, no.2, pp.548-559, 2012.

[50] M. A. E. Cunha, R. F. Neves, J. N. S. Souza, L. F. França, M. E. Araújo, G. Brunner, N. T. Machado, "Supercritical adsorption of buriti oil (Mauritia flexuosa Mart.) in $\gamma$-alumina: a methodology for the enriching of anti-oxidants", J. Supercrit. Fluids, vol.66, pp.181-191, 2012.

[51] G. E. Bolanos-Barrera, I. M. Mejia-Villareal, "Preparing an aqueous suspension of particles of a calcium salt comprises adding carbon dioxide compressed to a suspension of the calcium salt in a vessel, and passing the solution compressed by a nozzle", WO2012066389-A1, Colombia, 2010.

[52] G. E. Bolanos Barrera, V. F. Marulanda Cardona, B. G. E. Bolanos, C. V. F. Marulanda, "Toxic waste destruction comprises creating mixture of polluted environment and water, obtaining oxidizing agent, preheating, reacting in reaction unit, cooling, and removing and storing in gas stream and liquid stream", US2011237857-A1, Colombia, 2011.

[53] R. N. Cavalcanti, P. C. Veggi, M. A. A. Meireles, "Supercritical fluid extraction with a modifier of antioxidant compounds from jabuticaba (Myrciaria cauliflora) by-products: economic viability", Procedia Food Science, vol.1, pp.1672-1678, 2011.

[54] P. C. Veggi, D. T. Santos, M. A. A. Meireles, 2011, Anthocyanin extraction from Jabuticaba (Myrciaria cauliflora) skins by different techniques: economic evaluation, Proc. 11th International Congress on Engineering and Food,

[55] J. M. Prado, A. R. Assis, M. R. Maróstica-Júnior, M. A. A. Meireles, "Manufacturing cost of supercritical-extracted oils and carotenoids from amazonian plants", J Food Process Eng, vol.33, no.2, pp.348-369, 2010.

[56] C. L. C. Albuquerque, M. A. A. Meireles, "Defatting of annatto seeds using supercritical carbon dioxide as a pretreatment for the production of bixin: Experimental, modeling and economic evaluation of the process", J. Supercrit. Fluids, vol.66, pp.86-94, 2012.

[57] R. N. Cavalcanti, H. J. J. Navarro-Díaz, D. T. Santos, M. A. Rostagno, M. A. A. Meireles, "Supercritical carbon dioxide extraction of polyphenols from pomegranate (Punica granatum L.) leaves: chemical composition, economic evaluation and chemometric approach", J Food Res, vol.1, pp.282-294, 2012.

[58] J. M. Prado, I. Dalmolin, N. D. D. Carareto, R. C. Basso, A. J. A. Meirelles, J. V. Oliveira, E. A. C. Batista, M. A. A. Meireles, "Supercritical fluid extraction of grape seed: Process scale-up, extract chemical composition and economic evaluation", J Food Eng, vol.109, no.2, pp.249-257, 2012.

[59] J. M. Prado, G. H. C. Prado, M. A. A. Meireles, "Scale-up study of supercritical fluid extraction process for clove and sugarcane residue", J. Supercrit. Fluids, vol.56, no.3, pp.231-237, 2011.

[60] M. A. Fanovich, P. Jaeger, "Sorption and diffusion of compressed carbon dioxide in polycaprolactone for the development of porous scaffolds", Mat Sci Eng C - Mater Biol Appl, vol.32, no.4, pp.961-968, 2012.

[61] S. Simoncelli, P. A. Hoijemberg, M. Laura Japas, P. F. Aramendia, "Proton transfer from 2-naphthol to aliphatic 
amines in supercritical $\mathrm{CO}_{2}$ ", J. Phys. Chem. A, vol.115, no.50, pp.14243-14248, 2011.

[62] D. Royon, S. Locatelli, E. E. Gonzo, "Ketalization of glycerol to solketal in supercritical acetone", J. Supercrit. Fluids, vol.58, no.1, pp.88-92, 2011.

[63] N. Ganan, E. A. Brignole, "Fractionation of essential oils with biocidal activity using supercritical $\mathrm{CO}_{2}$-Experiments and modeling", J. Supercrit. Fluids, vol.58, no.1, pp.58-67, 2011.

[64] K. I. Gutkowski, R. Fernandez-Prini, P. F. Aramendia, M. Laura Japas, "Critical effects on attractive solutes in binary liquid mixtures close to their consolute point: A new experimental strategy", J. Phys. Chem. B, vol.115, no.51, pp.15303-15312, 2011.

[65] C. L. Ravazzoli, J. L. Gomez, "AVA seismic reflectivity analysis in carbon dioxide accumulations: Sensitivity to $\mathrm{CO}_{2}$ phase and saturation", J Appl Geophys, vol.73, no.2, pp.93-100, 2011.

[66] S. B. Rodriguez-Reartes, M. Cismondi, M. S. Zabaloy, "Computation of solid-fluid-fluid equilibria for binary asymmetric mixtures in wide ranges of conditions", J. Supercrit. Fluids, vol.57, no.1, pp.9-24, 2011.

[67] M. Cismondi, J. M. Mollerup, M. S. Zabaloy, "Equation of state modeling of the phase equilibria of asymmetric $\mathrm{CO}_{2}+$ n-alkane binary systems using mixing rules cubic with respect to mole fraction", J. Supercrit. Fluids, vol.55, no.2, pp.671-681, 2010.

[68] R. Fernandez-Prini, M. Laura Japas, E. Marceca, "Near-critical and supercritical dilute solutions viewed from macroscopic and molecular-scale perspectives", J. Supercrit. Fluids, vol.55, no.2, pp.472-478, 2010.

[69] J. M. Milanesio, G. D. B. Mabe, A. E. Ciolino, L. M. Quinzani, M. S. Zabaloy, "Experimental cloud points for polybutadiene plus light solvent and polyethylene plus light solvent systems at high pressure", J. Supercrit. Fluids, vol.55, no.1, pp.363-372, 2010.

[70] A. Velez, S. Pereda, E. A. Brignole, "Isochoric lines and determination of phase transitions in supercritical reactors", J. Supercrit. Fluids, vol.55, no.2, pp.643-647, 2010.

[71] A. Visentin, S. Rodriguez-Rojo, A. Navarrete, D. Maestri, M. J. Cocero, "Precipitation and encapsulation of rosemary antioxidants by supercritical antisolvent process", J Food Eng, vol.109, no.1, pp.9-15, 2012.

[72] A. Visentin, M. Cismondi, D. Maestri, "Supercritical $\mathrm{CO}_{2}$ fractionation of rosemary ethanolic oleoresins as a method to improve carnosic acid recovery", Innov Food Sci Emerg, vol.12, no.2, pp.142-145, 2011.

[73] R. E. Martini, E. A. Brignole, S. E. Barbosa, "Grafting of styrene onto polyethylene in near critical media", J. Appl. Polym. Sci., vol.123, no.5, pp.2787-2799, 2012.

[74] J. A. Pina, M. Hidalgo, D. Bragoni, Optimizing design in open channel, 2010.

[75] R. F. Cassimiro Belo, C. M. Nunes, E. V. dos Santos, D. V. Augusti, R. Pissinatti, "Single laboratory validation of a SPE method for the determination of PAHs in edible oils by GC-MS", Analytical Methods, vol.4, no.12, pp.4068-4076, 2012 .
[76] M. A. E. Cunha, R. F. Neves, J. N. S. Souza, L. F. Franca, M. E. Araujo, G. Brunner, N. T. Machado, "Supercritical adsorption of buriti oil (Mauritia flexuosa Mart.) in gamma-alumina: a methodology for the enriching of anti-oxidants", J. Supercrit. Fluids, vol.66, pp.181-191, 2012.

[77] M. R. Kviecinski, P. Benelli, K. B. Felipe, J. F. G. Correia, C. T. Pich, S. R. S. Ferreira, R. C. Pedrosa, "SFE from Bidens pilosa Linne to obtain extracts rich in cytotoxic polyacetylenes with antitumor activity", J. Supercrit. Fluids, vol.56, no.3, pp.243-248, 2011.

[78] S. Siqueira, V. d. S. Falcao-Silva, M. d. F. Agra, C. Dariva, J. P. de Siqueira-Junior, M. J. Vieira Fonseca, "Biological activities of Solanum paludosum moric. extracts obtained by maceration and supercritical fluid extraction", J. Supercrit. Fluids, vol.58, no.3, pp.391-397, 2011.

[79] L. C. Paviani, C. Dariva, M. C. Marcucci, F. A. Cabral, "Supercritical carbon dioxide selectivity to fractionate phenolic compounds from the dry ethanolic extract of propolis", J Food Process Eng, vol.33, no.1, pp.15-27, 2010.

[80] N. Mezzomo, E. de Paz, M. Maraschin, A. Martin, M. Jose Cocero, S. R. S. Ferreira, "Supercritical anti-solvent precipitation of carotenoid fraction from pink shrimp residue: Effect of operational conditions on encapsulation efficiency", J. Supercrit. Fluids, vol.66, pp.342-349, 2012.

[81] J. M. Prado, A. R. Assis, M. R. Marostica-Junior, M. A. A. Meireles, "Manufacturing cost of supercritical-extracted oils and carotenoids from amazonian plants", J Food Process Eng, vol.33, no.2, pp.348-369, 2010.

[82] E. G. Pereira, J. N. da Silva, J. L. de Oliveira, C. S. Machado, "Sustainable energy: A review of gasification technologies", Renew Sust Energ Rev, vol.16, no.7, pp.4753-4762, 2012.

[83] E. M. Z. Michielin, L. P. de Lemos Wiese, E. A. Ferreira, R. C. Pedrosa, S. R. S. Ferreira, "Radical-scavenging activity of extracts from Cordia verbenacea DC obtained by different methods", J. Supercrit. Fluids, vol.56, no.1, pp.89-96, 2011.

[84] F. Agostini, R. A. Bertussi, G. Agostini, A. C. A. dos Santos, M. Rossato, R. Vanderlinde, "Supercritical extraction from vinification residues: Fatty acids, alpha-tocopherol, and phenolic compounds in the oil seeds from different varieties of grape", Sci World J, vol.pp.1-9, 2012.

[85] E. L. Galvao, J. Martinez, H. N. Maia De Oliveira, E. M. Bittencourt Dutra De Sousa, "Supercritical extraction of linseed oil: Economical viability and modeling extraction curves", Chem. Eng. Commun., vol.200, no.2, pp.205-221, 2013.

[86] F. A. Pimentel, M. d. G. Cardoso, L. G. L. Guimaraes, F. Queiroz, L. C. A. Barbosa, A. R. Morais, D. L. Nelson, M. A. Andrade, L. M. Zacaroni, S. M. N. P. Pimentel, "Extracts from the leaves of Piper piscatorum (Trel. Yunc.) obtained by supercritical extraction of with $\mathrm{CO}_{2}$, employing ethanol and methanol as co-solvents", Ind Crop Prod, vol.43, pp.490-495, 2013.

[87] A. C. Aguiar, J. V. Visentainer, J. Martinez, "Extraction from striped weakfish (Cynoscion striatus) wastes with pressurized $\mathrm{CO}_{2}$ : Global yield, composition, kinetics and cost estimation", J. Supercrit. Fluids, vol.71, pp.1-10, 2012.

[88] C. L. C. Albuquerque, M. A. A. Meireles, "Defatting of 
annatto seeds using supercritical carbon dioxide as a pretreatment for the production of bixin: Experimental, modeling and economic evaluation of the process", J. Supercrit. Fluids, vol.66, pp.86-95, 2012.

[89] K. S. Andrade, R. T. Goncalvez, M. Maraschin, R. M. Ribeiro-do-Valle, J. Martinez, S. R. S. Ferreira, "Supercritical fluid extraction from spent coffee grounds and coffee husks: Antioxidant activity and effect of operational variables on extract composition", Talanta, vol.88, pp.544-552, 2012.

[90] V. d. S. Carrara, L. Z. Serra, L. Cardozo-Filho, E. F. Cunha-Junior, E. C. Torres-Santos, D. A. Garcia Cortez, "HPLC Analysis of supercritical carbon dioxide and compressed propane extracts from Piper amalago L. with antileishmanial activity", Molecules, vol.17, no.1, pp.15-33, 2012.

[91] R. H. R. Carvalho, E. L. Galvao, J. A. C. Barros, M. M. Conceicao, E. M. B. D. Sousa, "Extraction, fatty acid profile and antioxidant activity of sesame extract (Sesamum Indicum L.)", Braz J Chem Eng, vol.29, no.2, pp.409-420, 2012.

[92] N. C. F. Correa, C. d. S. Macedo, J. d. F. C. Moraes, N. T. Machado, L. F. de Franca, "Characteristics of the extract of Litopenaeus vannamei shrimp obtained from the cephalothorax using pressurized $\mathrm{CO}_{2}$ ", J. Supercrit. Fluids, vol.66, pp.176-180, 2012.

[93] D. A. G. Cortez, V. da Silva Carrara, L. Z. Serra, L. Cardozo-Filho, E. F. Cunha-Junior, E. C. Torres-Santos, L. E. R. Cortez, "HPLC analysis and antileishmanial activity of supercritical fluids extracts from Piper amalago L", Planta Med., vol.78, no.11, pp.1266-1266, 2012.

[94] P. F. de Oliveira, R. A. Francisco Machado, A. Bolzan, D. Barth, "Supercritical fluid extraction of hernandulcin from Lippia dulcis Trev", J. Supercrit. Fluids, vol.63, pp.161-168, 2012.

[95] V. A. dos Santos Garcia, V. F. Cabral, E. F. Zanoelo, C. da Silva, L. Cardozo Filho, "Extraction of mucuna seed oil using supercritical carbon dioxide to increase the concentration of L-Dopa in the defatted meal", J. Supercrit. Fluids, vol.69, pp.75-81, 2012.

[96] S. Mazzutti, S. R. S. Ferreira, C. A. S. Riehl, A. Smania, Jr., F. A. Smania, J. Martinez, "Supercritical fluid extraction of Agaricus brasiliensis: Antioxidant and antimicrobial activities", J. Supercrit. Fluids, vol.70, pp.48-56, 2012.

[97] L. G. Mueller, L. d. A. Salles, S. Sakamoto, A. C. Stein, S. T. Cargnin, E. Cassel, R. F. Vargas, S. M. Kuze Rates, G. L. von Poser, "Effect of storage time and conditions on the diene valepotriates content of the extract of Valeriana glechomifolia obtained by supercritical carbon dioxide", Phytochem. Anal., vol.23, no.3, pp.222-227, 2012.

[98] E. B. Parisotto, E. M. Z. Michielin, F. Biscaro, S. R. S. Ferreira, D. Wilhelm Filho, R. C. Pedrosa, "The antitumor activity of extracts from Cordia verbenacea DC obtained by supercritical fluid extraction", J. Supercrit. Fluids, vol.61, pp.101-107, 2012.

[99] J. M. Prado, I. Dalmolin, N. D. D. Carareto, R. C. Basso, A. J. A. Meirelles, J. Vladimir Oliveira, E. A. C. Batista, M. A. A. Meireles, "Supercritical fluid extraction of grape seed: Process scale-up, extract chemical composition and economic evaluation", J Food Eng, vol.109, no.2, pp.249-257, 2012.

[100] A. P. Sanchez-Camargo, M. A. A. Meireles, A. L. K. Ferreira, E. Saito, F. A. Cabral, "Extraction of omega-3 fatty acids and astaxanthin from Brazilian redspotted shrimp waste using supercritical $\mathrm{CO}_{2}+$ ethanol mixtures", J. Supercrit. Fluids, vol.61, pp.71-77, 2012.

[101] D. Sandi, J. M. A. Araujo, E. J. Montes-Montes, J. S. R. Coimbra, S. R. S. Ferreira, "Modeling oil extraction from green and roasted coffee by means of supercritical $\mathrm{CO}_{2}$ ", Int J Food Eng, vol.8, no.1, 2012.

[102] C. O. Terra Lemos, V. A. dos Santos Garcia, R. M. Goncalves, I. C. Ramos Leal, V. L. Dias Siqueira, L. Cardozo Filho, V. F. Cabral, "Supercritical extraction of neolignans from Piper regnelli var. pallescens", J. Supercrit. Fluids, vol.71, pp.64-70, 2012.

[103]F. M. C. Barros, F. C. Silva, J. M. Nunes, R. M. F. Vargas, E. Cassel, G. L. von Poser, "Supercritical extraction of phloroglucinol and benzophenone derivatives from Hypericum carinatum: Quantification and mathematical modeling", J. Sep. Sci., vol.34, no.21, pp.3107-3113, 2011.

[104]M. S. T. Barroso, G. Villanueva, A. M. Lucas, G. P. Perez, R. M. F. Vargas, G. W. Brun, E. Cassel, "Supercritical fluid extraction of volatile and non-volatile compounds from Schinus molle L", Braz J Chem Eng, vol.28, no.2, pp.305-312, 2011.

[105] R. M. Goncalves, C. O. Lemos, V. A. Garcia, E. M. Santos, L. C. Filho, V. F. Cabral, D. A. Cortez, J. S. Godoy, P. S. Mendonca, T. I. Svidzinski, "Antifungal activity of supercritical fluid extract obtained from Calophyllum brasiliense Cambess", Planta Med., vol.77, no.12, pp.1420-1420, 2011.

[106] M. E. Machado, F. C. Fontanive, J. V. de Oliveira, E. B. Caramao, C. A. Zini, "Identification of organic sulfur compounds in coal bitumen obtained by different extraction techniques using comprehensive two-dimensional gas chromatography coupled to time-of-flight mass spectrometric detection", Anal. Bioanal. Chem., vol.401, no.8, pp.2433-2444, 2011.

[107] F. S. Malaman, L. A. B. Moraes, C. West, N. J. Ferreira, A. L. Oliveira, "Supercritical fluid extracts from the Brazilian cherry (Eugenia uniflora L.): Relationship between the extracted compounds and the characteristic flavour intensity of the fruit", Food Chem., vol.124, no.1, pp.85-92, 2011.

[108] N. Mezzomo, B. Maestri, R. L. dos Santos, M. Maraschin, S. R. S. Ferreira, "Pink shrimp (P. brasiliensis and P. paulensis) residue: Influence of extraction method on carotenoid concentration", Talanta, vol.85, no.3, pp.1383-1391, 2011.

[109] G. Nimet, E. A. Da Silva, F. Palu, C. Dariva, L. d. S. Freitas, A. Medina Neto, L. Cardozo Filho, "Extraction of sunflower (Heliantus annuus L.) oil with supercritical $\mathrm{CO}_{2}$ and subcritical propane: Experimental and modeling", Chem Eng J, vol.168, no.1, pp.262-268, 2011.

[110]T. R. Pasquali, S. M. D. Macedo, S. S. Roman, V. Dal Pra, R. L. Cansian, A. J. Mossi, V. J. Oliveira, M. A. Mazutti, "Acute toxicity and anti inflammatory effects of supercritical extracts of Ilex paraguariensis", Afr J Pharm Pharmaco, vol.5, no.8, pp.1162-1169, 2011.

[111] M. M. Pederssetti, F. Palu, E. A. da Silva, J. H. Rohling, L. 
Cardozo-Filho, C. Dariva, "Extraction of canola seed (Brassica napus) oil using compressed propane and supercritical carbon dioxide", J Food Eng, vol.102, no.2, pp.189-196, 2011.

[112] E. Rahimi, J. M. Prado, G. Zahedi, M. A. A. Meireles, "Chamomile extraction with supercritical carbon dioxide: Mathematical modeling and optimization", J. Supercrit. Fluids, vol.56, no.1, pp.80-88, 2011.

[113] A. P. Sanchez-Camargo, H. A. Martinez-Correa, L. C. Paviani, F. A. Cabral, "Supercritical $\mathrm{CO}_{2}$ extraction of lipids and astaxanthin from Brazilian redspotted shrimp waste (Farfantepenaeus paulensis)", J. Supercrit. Fluids, vol.56, no.2, pp.164-173, 2011.

[114] A. P. Sanchez-Camargo, M. A. Almeida Meireles, B. L. Fontoura Lopes, F. A. Cabral, "Proximate composition and extraction of carotenoids and lipids from Brazilian redspotted shrimp waste (Farfantepenaeus paulensis)", J Food Eng, vol.102, no.1, pp.87-93, 2011.

[115] L. L. B. Santana, C. V. Silva, L. C. Almeida, T. A. C. Costa, E. S. Velozo, "Extraction with supercritical fluid and comparison of chemical composition from adults and young leaves of Zanthoxylum tingoassuiba", Rev Bras Farmacogn, vol.21, no.3, pp.564-567, 2011.

[116] P. Benelli, C. A. S. Riehl, A. Smania, Jr., E. F. A. Smania, S. R. S. Ferreira, "Bioactive extracts of orange (Citrus sinensis L. Osbeck) pomace obtained by SFE and low pressure techniques: Mathematical modeling and extract composition", J. Supercrit. Fluids, vol.55, no.1, pp.132-141, 2010.

[117] S. T. Cargnin, J. d. M. Nunes, J. S. Haas, L. F. Baladao, E. Cassel, R. F. Vargas, S. B. Rech, G. L. von Poser, "Supercritical fluid extraction and high performance liquid chromatographic determination of benzopyrans and phloroglucinol derivative in Hypericum polyanthemum", J Chromatogr B, vol.878, no.1, pp.83-87, 2010.

[118] E. Cassel, R. M. Figueiro Vargas, G. W. Brun, D. E. Almeida, L. Cogoi, G. Ferraro, R. Filip, "Supercritical fluid extraction of alkaloids from Ilex paraguariensis St. Hil", J Food Eng, vol.100, no.4, pp.656-661, 2010.

[119] M. P. Corso, M. R. Fagundes-Klen, E. A. Silva, L. Cardozo Filho, J. N. Santos, L. S. Freitas, C. Dariva, "Extraction of sesame seed (Sesamun indicum L.) oil using compressed propane and supercritical carbon dioxide", J. Supercrit. Fluids, vol.52, no.1, pp.56-61, 2010.

[120] J. A. Egydio, A. M. Moraes, P. T. V. Rosa, "Supercritical fluid extraction of lycopene from tomato juice and characterization of its antioxidation activity", J. Supercrit. Fluids, vol.54, no.2, pp.159-164, 2010.

[121] S. P. Jesus, R. Grimaldi, H. Hense, "Recovery of gamma-oryzanol from rice bran oil byproduct using supercritical fluid extraction", J. Supercrit. Fluids, vol.55, no.1, pp.149-155, 2010.

[122]N. Mezzomo, B. R. Mileo, M. T. Friedrich, J. Martinez, S. R. S. Ferreira, "Supercritical fluid extraction of peach (Prunus persica) almond oil: Process yield and extract composition", Bioresour. Technol., vol.101, no.14, pp.5622-5632, 2010.

[123] E. W. Nascimento da Fonseca Contado, L. d. S. Patto, D. A. Rocha, C. M. Patto de Abreu, A. D. Correa, C. D. dos Santos, "A study of the methods of carotenoid extraction in carrots using supercritical fluid extraction (SFE) and conventional methods", Cienc Agrotec, vol.34, pp.1617-1623, 2010.

[124] S. R. Rosso Comim, K. Madella, J. V. Oliveira, S. R. S. Ferreira, "Supercritical fluid extraction from dried banana peel (Musa spp., genomic group AAB): Extraction yield, mathematical modeling, economical analysis and phase equilibria", J. Supercrit. Fluids, vol.54, no.1, pp.30-37, 2010.

[125] T. M. Takeuchi, M. L. Rubano, M. A. A. Meireles, "Characterization and functional properties of macela (Achyrocline satureioides) extracts obtained by supercritical fluid extraction using mixtures of $\mathrm{CO}_{2}$ plus ethanol", Food Bioprocess Tech, vol.3, no.6, pp.804-812, 2010.

[126] C. E. Vargas, M. F. Mendes, D. A. Azevedo, F. L. P. Pessoa, A. C. Uller, "Extraction of the essential oil of abajeru (Chrysobalanus icaco) using supercritical $\mathrm{CO}_{2}$ ", J. Supercrit. Fluids, vol.54, no.2, pp.171-177, 2010.

[127] J. C. dos Santos, H. R. Mazzer, G. D. Machado, J. Andreaus, V. F. Cabral, M. S. Zabaloy, L. Cardozo-Filho, "High-pressure phase behaviour of the system $\left(\mathrm{CO}_{2}+\mathrm{CI}\right.$ Disperse Orange 30 dye)", J. Chem. Thermodyn., vol.48, pp.284-290, 2012.

[128] B. L. F. Lopes, A. P. Sanchez-Camargo, A. L. K. Ferreira, R. Grimaldi, L. C. Paviani, F. A. Cabral, "Selectivity of supercritical carbon dioxide in the fractionation of fish oil with a lower content of EPA plus DHA", J. Supercrit. Fluids, vol.61, pp.78-85, 2012.

[129] V. B. Soares, G. L. V. Coelho, "Safety study of an experimental apparatus for extraction with supercritical $\mathrm{CO}_{2}$ ", Braz J Chem Eng, vol.29, no.3, pp.677-682, 2012.

[130] F. V. Correa, S. R. R. Comim, A. M. de Cesaro, A. A. Rigo, M. A. Mazutti, H. Hense, J. V. Oliveira, "Phase equilibrium data for the ternary system (propane plus chloroform plus oryzanol)", J. Chem. Thermodyn., vol.43, no.1, pp.34-38, 2011.

[131] D. T. dos Santos, A. F. Sotelo, B. F. Sarrouh, L. M. Salaue, N. R. Palacios, S. S. Silva, "Supercritical technology as an alternative for biotechnological xylitol purification", Semin-Cienc Agrar, vol.32, no.2, pp.621-632, 2011.

[132] F. M. Ferreira, L. P. Ramos, P. M. Ndiaye, M. L. Corazza, "Phase behavior of $\left(\mathrm{CO}_{2}+\right.$ methanol plus lauric acid $)$ system", J. Chem. Thermodyn., vol.43, no.7, pp.1074-1082, 2011.

[133] W. M. Giufrida, S. B. Rodriguez-Reartes, C. G. Alonso, M. S. Zabaloy, V. F. Cabral, F. W. Tavares, L. Cardozo-Filho, "High-pressure experimental data of $\mathrm{CO}_{2}+$ Mitotane and $\mathrm{CO}_{2}+$ Ethanol plus Mitotane mixtures", J. Chem. Eng. Data, vol.56, no.12, pp.4333-4341, 2011.

[134] P. F. Arce, M. Aznar, "Thermodynamic modeling of liquid-fluid phase equilibrium in supercritical ethylene plus copolymer plus co-solvent systems using the PC-SAFT equation of state", J. Supercrit. Fluids, vol.52, no.1, pp.18-29, 2010.

[135] J. P. Bender, M. Feitein, E. Franceschi, M. L. Corazza, J. V. Oliveira, "Phase behaviour of binary systems of lactones in carbon dioxide", J. Chem. Thermodyn., vol.42, no.1, pp.48-53, 2010.

[136] J. P. Bender, M. Feitein, M. A. Mazutti, E. Franceschi, M. L. Corazza, J. V. Oliveira, "Phase behaviour of the ternary 
system \{poly(epsilon-caprolactone) plus carbon dioxide plus dichloromethane\}", J. Chem. Thermodyn., vol.42, no.2, pp.229-233, 2010.

[137]R. M. Charin, M. L. Corazza, P. M. Ndiaye, M. A. Mazutti, J. Vladimir Oliveira, "Phase equilibrium data and thermodynamic modeling of the system propane plus NMP plus methanol at high pressures ", J. Supercrit. Fluids, vol.55, no.2, pp.662-670, 2010 .

[138]S. R. R. Comim, E. Franceschi, G. R. Borges, M. L. Corazza, J. V. Oliveira, S. R. S. Ferreira, "Phase equilibrium measurements and modelling of ternary system (carbon dioxide plus ethanol plus palmitic acid)", J. Chem. Thermodyn., vol.42, no.3, pp.348-354, 2010.

[139] R. Favareto, J. R. D. Pereira, C. C. Santana, E. H. Madureira, V. F. Cabral, F. W. Tavares, L. Cardozo-Filho, "High-pressure phase diagram of the drug mitotane in compressed and/or supercritical $\mathrm{CO}_{2}$ ", J. Chem. Thermodyn., vol.42, no. 2 , pp.286-290, 2010.

[140] M. Waltrich, C. J. L. Hermes, J. M. Goncalves, C. Melo, "A first-principles simulation model for the thermo-hydraulic performance of fan supplied tube-fin heat exchangers", Appl Therm Eng, vol.30, no.14-15, pp.2011-2018, 2010.

[141] C. Steffens, M. L. Corazza, E. Franceschi, F. Castilhos, P. S. P. Herrmann, Jr., J. Vladimir Oliveira, "Development of gas sensors coatings by polyaniline using pressurized fluid", Sensor Actuat B-Chem, vol.171, pp.627-633, 2012.

[142] M. Bertoncini, L. A. Ferreira Coelho, I. O. Maciel, S. H. Pezzin, "Purification of single-wall carbon nanotubes by heat treatment and supercritical extraction", Mater Res-Ibero-Am J, vol.14, no.3, pp.380-383, 2011.

[143] V. Lima, S. Einloft, J. M. Ketzer, M. Jullien, O. Bildstein, J.-C. Petronin, "CO $\mathrm{CO}_{2}$ Geological storage in saline aquifers: Parana basin caprock and reservoir chemical reactivity", Energy Procedia, vol.4, pp.5377-5384, 2011.

[144] M. R. Mauricio, F. C. G. Manso, M. H. Kunita, D. S. Velasco, A. C. Bento, E. C. Muniz, G. M. de Carvalho, A. F. Rubira, "Synthesis and characterization of $\mathrm{ZnO} / \mathrm{PET}$ composite using supercritical carbon dioxide impregnation technology", Compos Part A-Appl S, vol.42, no.7, pp.757-761, 2011.

[145] N. Mezzomo, J. Martinez, S. R. S. Ferreira, "Economical viability of SFE from peach almond, spearmint and marigold", J Food Eng, vol.103, no.4, pp.473-479, 2011.

[146]F. d. A. Fin de Lima, O. A. Andreo dos Santos, N. Pinheiro, "Impregnation of composite from polycarbonate (PC) and silica gel $(\mathrm{Si})$ films with photochromic dye in supercritical fluid", Acta Sci-Technol, vol.32, no.1, pp.69-74, 2010.

[147] A. L. dos Santos Lima, K. d. S. C. Lima, T. C. C. Franca, M. I. B. Tavares, R. A. da Silva San-Gil, M. N. Eberlin, A. C Pinto, "Mesophase evolution in heat-treated solid petroleum pitches", J. Braz. Chem. Soc., vol.23, no.7, pp.1355-1371, 2012.

[148] R. Z. Moreno, R. G. Santos, C. Okabe, D. J. Schiozer, O. V. Trevisan, E. Bonet, S. Iatchuk, "Comparison of residual oil saturation for water and supercritical $\mathrm{CO}_{2}$ flooding in a long core, with live oil at reservoir conditions", J Porous Media, vol.14, no.8, pp.699-708, 2011.

[149] D. F. de Andrade, D. R. Fernandes, J. L. Miranda, "Methods for the determination of conjugated dienes in petroleum products: A review", Fuel, vol.89, no.8, pp.1796-1805, 2010.

[150] M. C. Gutierrez, P. d. T. V. e. Rosa, M.-A. De Paoli, M. I. Felisberti, "Biocomposites based on cellulose acetate and short curaua fibers treated with supercritical $\mathrm{CO}_{2}{ }^{\prime \prime}$, Polimeros, vol.22, no.3, pp.295-302, 2012.

[151] L. Monks, L. Tiggamann, M. A. Mazuti, V. J. Oliveira, E. Valduga, "Assessment of carotenoids recovery through cell rupture of Sporidiobolus salmonicolor CBS 2636 using compressed fluids", Food Bioprocess Tech, vol.5, no.6, pp.2353-2359, 2012.

[152] G. d. O. Kuhn, C. Coghetto, H. Treichel, D. de Oliveira, J. Vladimir Oliveira, "Effect of compressed fluids treatment on the activity of inulinase from Kluyveromyces marxianus NRRL Y-7571 immobilized in montmorillonite", Process Biochem, vol.46, no.12, pp.2286-2290, 2011.

[153] A. P. Manera, G. Kuhn, A. Polloni, M. Marangoni, G. Zabot, S. J. Kalil, D. de Oliveira, H. Treichel, J. Vladimir Oliveira, M. A. Mazutti, F. Maugeri, "Effect of compressed fluids treatment on the activity, stability and enzymatic reaction performance of beta-galactosidase", Food Chem., vol.125, no.4, pp.1235-1240, 2011.

[154] R. O. Cristovao, P. F. F. Amaral, A. P. M. Tavares, M. A. Z. Coelho, M. C. Cammarota, J. M. Loureiro, R. A. R. Boaventura, E. A. Macedo, F. L. P. Pessoa, "Optimization of laccase catalyzed degradation of reactive textile dyes in supercritical carbon dioxide medium by response surface methodology", React Kinet Mechan Catal, vol.99, no.2, pp.311-323, 2010.

[155] A. T. Fricks, C. Dariva, H. M. Alvarez, A. F. Santos, M. Fortuny, M. L. Barreto Queiroz, O. A. C. Antunes, "Compressed propane as a new and fast method of pre-purification of radish (Raphanus sativus L.) peroxidase", J. Supercrit. Fluids, vol.54, no.2, pp.153-158, 2010.

[156]L. P. Gomes Franken, N. S. Marcon, H. Treichel, D. Oliveira, D. M. G. Freire, C. Dariva, J. Destain, J. V. Oliveira, "Effect of treatment with compressed propane on lipases hydrolytic activity", Food Bioprocess Tech, vol.3, no.4, pp.511-520, 2010 .

[157] F. Pelascini, S. Plentz-Meneghetti, P. J. Lutz, V. Krukonis, $\mathrm{K}$. Williams, "Branched polyethylenes fractionated in supercritical propane", Macromol. Res., vol.18, no.5, pp.449-457, 2010.

[158] R. C. Rodrigues, R. Fernandez-Lafuente, "Lipase from Rhizomucor miehei as a biocatalyst in fats and oils modification", J Mol Catal B-Enzym, vol.66, no.1-2, pp.15-32, 2010.

[159]R. C. Rodrigues, R. Fernandez-Lafuente, "Lipase from Rhizomucor miehei as an industrial biocatalyst in chemical process", J Mol Catal B-Enzym, vol.64, no.1-2, pp.1-22, 2010.

[160] B. D. Ribeiro, D. W. Barreto, M. A. Zarur Coelho, "Technological aspects of beta-carotene production", Food Bioprocess Tech, vol.4, no.5, pp.693-701, 2011.

[161] R. d. C. Oliveira, R. E. Santelli, "Occurrence and chemical speciation analysis of organotin compounds in the environment: A review", Talanta, vol.82, no.1, pp.9-24, 2010 . 
[162] C. G. Pereira, M. A. A. Meireles, "Supercritical fluid extraction of bioactive compounds: Fundamentals, applications and economic perspectives", Food Bioprocess Tech, vol.3, no.3, pp.340-372, 2010.

[163] M. Eugenia Letelier, P. Aracena-Parks, L. Peredo-Silva, "A protocol for evaluating the safety of herbal preparations in a rat model: the case of a supercritical fluid extract of Saw Palmetto", Bol Latinoam Caribe, vol.9, no.1, pp.69-79, 2010.

[164] N. Romero, A. Fernandez, P. Robert, "A polyphenol extract of tara pods (Caesalpinia spinosa) as a potential antioxidant in oils", Eur. J. Lipid Sci. Technol., vol.114, no.8, pp.951-957, 2012.

[165] E. Uquiche, V. Romero, J. Ortiz, J. M. del Valle, "Extraction of oil and minor lipids from cold-press rapeseed cake with supercritical $\mathrm{CO}_{2}{ }^{\prime \prime}$, Braz J Chem Eng, vol.29, no.3, pp.585-597, 2012.

[166] E. Uquiche, E. Huerta, A. Sandoval, J. Manuel del Valle, "Effect of boldo (Peumus boldus M.) pretreatment on kinetics of supercritical $\mathrm{CO}_{2}$ extraction of essential oil", J Food Eng, vol.109, no.2, pp.230-237, 2012.

[167] J. M. Valle, J. C. Fuente, E. Uquiche, C. Zetzl, G. Brunner, Mass transfer and equilibrium parameters on high-pressure $\mathrm{CO}_{2}$ extraction of plant essential oils, in Food Engineering Interfaces, J. M. Aguilera, R. Simpson, J. Welti-Chanes, D. Bermudez-Aguirre, G. Barbosa-Canovas. Springer New York, 2011 .

[168] P. Jimenez, L. Masson, A. Barriga, J. Chavez, P. Robert, "Oxidative stability of oils containing olive leaf extracts obtained by pressure, supercritical and solvent-extraction", Eur. J. Lipid Sci. Technol., vol.113, no.4, pp.497-505, 2011.

[169] L. E. Laroze, B. Diaz-Reinoso, A. Moure, M. Elvira Zuniga, H. Dominguez, "Extraction of antioxidants from several berries pressing wastes using conventional and supercritical solvents", Eur. Food Res. Technol., vol.231, no.5, pp.669-677, 2010.

[170] J. M. del Valle, J. C. de la Fuente, E. Uquiche, "A refined equation for predicting the solubility of vegetable oils in high-pressure $\mathrm{CO}_{2}$ ", J. Supercrit. Fluids, vol.67, pp.60-70, 2012 .

[171] J. M. del Valle, F. A. Urrego, "Free solute content and solute-matrix interactions affect apparent solubility and apparent solute content in supercritical $\mathrm{CO}_{2}$ extractions. A hypothesis paper", J. Supercrit. Fluids, vol.66, pp.157-175, 2012.

[172] M. Jose Tardon, J. Matias Garrido, H. Quinteros-Lama, A. Mejia, H. Segura, "Molar isopycnicity in heterogeneous binary mixtures", Fluid Phase Equilib., vol.336, pp.84-97, 2012.

[173] J. A. Lazzus, "Optimization of a cubic equation of state and van der Waals mixing rules for modeling the phase behavior of complex mixtures", Rev Mex Fis, vol.58, no.6, pp.510-514, 2012.

[174] R. Lemus-Mondaca, A. Vega-Galvez, L. Zura-Bravo, K. Ah-Hen, "Stevia rebaudiana Bertoni, source of a high-potency natural sweetener: A comprehensive review on the biochemical, nutritional and functional aspects", Food Chem., vol.132, no.3, pp.1121-1132, 2012.
[175]K. A. Araus, R. I. Canales, J. M. del Valle, J. C. de la Fuente, "Solubility of beta-carotene in ethanol- and triolein-modified $\mathrm{CO}_{2}$ ", J. Chem. Thermodyn., vol.43, no.12, pp.1991-2001, 2011.

[176] G. A. Nunez, C. A. Gelmi, J. M. del Valle, "Simulation of a supercritical carbon dioxide extraction plant with three extraction vessels", Comput. Chem. Eng., vol.35, no.12, pp.2687-2695, 2011.

[177] G. A. Nunez, J. M. del Valle, J. C. de la Fuente, "Solubilities in supercritical carbon dioxide of (2E,6E)-3,7,11-Trimethyldodeca-2,6,10-trien-1-ol (Farnesol) and (2S)-5,7-Dihydroxy-2-(4-hydroxyphenyl)chroman-4-one (Naringenin)", J. Chem. Eng. Data, vol.55, no.9, pp.3863-3868, 2010.

[178] J. O. Valderrama, P. A. Robles, A. Reategui, "Data analysis, modeling and thermodynamic consistency of $\mathrm{CO}_{2}+$ beta-carotene high pressure mixtures", J. Supercrit. Fluids, vol.55, no.2, pp.609-615, 2010.

[179] A. Illanes, A. Cauerhff, L. Wilson, G. R. Castro, "Recent trends in biocatalysis engineering", Bioresour. Technol., vol.115, pp.48-57, 2012.

[180]H. I. Castro-Vargas, L. I. Rodriguez-Varela, S. R. S. Ferreira, F. Parada-Alfonso, "Extraction of phenolic fraction from guava seeds (Psidium guajava L.) using supercritical carbon dioxide and co-solvents", J. Supercrit. Fluids, vol.51, no.3, pp.319-324, 2010.

[181] J. R. Forero-Mendieta, H. I. Castro-Vargas, F. Parada-Alfonso, J. A. Guerrero-Dallos, "Extraction of pesticides from soil using supercritical carbon dioxide added with methanol as co-solvent", J. Supercrit. Fluids, vol.68, pp.64-70, 2012.

[182] I. X. Ceron, J. C. Higuita, C. A. Cardona, "Design and analysis of antioxidant compounds from Andes Berry fruits (Rubus glaucus Benth) using an enhanced-fluidity liquid extraction process with $\mathrm{CO}_{2}$ and ethanol", J. Supercrit. Fluids, vol.62, pp.96-101, 2012.

[183] J. A. Rocha Uribe, J. I. Novelo Perez, H. Castillo Kauil, G. Rosado Rubio, C. Guillermo Alcocer, "Extraction of oil from chia seeds with supercritical $\mathrm{CO}_{2}$ ", J. Supercrit. Fluids, vol.56, no.2, pp.174-178, 2011.

[184]H. I. Castro-Vargas, L. I. Rodriguez-Varela, F. Parada-Alfonso, "Guava (Psidium guajava L.) seed oil obtained with a homemade supercritical fluid extraction system using supercritical $\mathrm{CO}_{2}$ and co-solvent", J. Supercrit. Fluids, vol.56, no.3, pp.238-242, 2011.

[185] E. E. Stashenko, J. R. Martinez, C. A. Ruiz, G. Arias, C. Duran, W. Salgar, M. Cala, "Lippia origanoides chemotype differentiation based on essential oil GC-MS and principal component analysis", J. Sep. Sci., vol.33, no.1, pp.93-103, 2010 .

[186] M. A. Hernandez-Acosta, H. I. Castro-Vargas, F. Parada-Alfonso, "Integrated utilization of guava (Psidium guajava L.): Antioxidant activity of phenolic extracts obtained from guava seeds with supercritical $\mathrm{CO}_{2}$-Ethanol", J. Braz. Chem. Soc., vol.22, no.12, pp.2383-2390, 2011.

[187] M. J. Parra, A. Y. Leon, L. J. Hoyos, "Separation of fractions from vacuum residue by supercritical extraction", Cienc Tecnol Fut, vol.4, no.2, pp.83-90, 2010. 
[188] V. Marulanda, "Reacting flow simulations of supercritical water oxidation of PCB-contaminated transformer oil in a pilot plant reactor", Braz J Chem Eng, vol.28, no.2, pp.285-294, 2011.

[189] V. F. Marulanda, G. Anitescu, L. L. Tavlarides, "Biodiesel fuels through a continuous flow process of chicken fat supercritical transesterification", Energ Fuel, vol.24, pp.253-260, 2010.

[190] G. A. Mendez-Maldonado, M. Gonzalez-Melchor, J. Alejandre, G. A. Chapela, "On the centre of mass velocity in molecular dynamics simulations", Rev Mex Fis, vol.58, no.1, pp.55-60, 2012.

[191] A. Mendoza-Galvan, C. Trejo-Cruz, O. Solis-Canto, G. Luna-Barcenas, "Effect of a temperature gradient on ellipsometry measurements in supercritical $\mathrm{CO}_{2} "$, J. Supercrit. Fluids, vol.64, pp.25-31, 2012.

[192] A. M. Catano-Barrera, F. L. Figueira, C. Olivera-Fuentes, C. M. Colina, "Correlation and prediction of fluid-fluid equilibria of carbon dioxide-aromatics and carbon dioxide-dichlorobenzoates binary mixtures", Fluid Phase Equilib., vol.311, pp.45-53, 2011.

[193]J. Cruz-Olivares, C. H. Ortiz-Estrada, C. Perez-Alonso, M. C. Chaparro-Mercado, C. Barrera-Diaz, "Solubility of mesquite gum in supercritical carbon dioxide", J. Chem. Eng. Data, vol.56, no.5, pp.2449-2452, 2011.

[194] O. Elizalde-Solis, L. A. Galicia-Luna, "New apparatus for solubility measurements of solids in carbon dioxide", Ind. Eng. Chem. Res., vol.50, no.1, pp.207-212, 2011.

[195] P. Tellez-Arredondo, M. Medeiros, M. M. Pineiro, C. A.
Cerdeirina, "Loci of extrema of thermodynamic response functions for the Lennard-Jones fluid", Mol. Phys., vol.109, no.20, pp.2443-2449, 2011.

[196] L. Brandt, O. Elizalde-Solis, L. A. Galicia-Luna, J. Gmehling, "Solubility and density measurements of palmitic acid in supercritical carbon dioxide plus alcohol mixtures", Fluid Phase Equilib., vol.289, no.1, pp.72-79, 2010.

[197] M. del Socorro Vergara-Mendoza, C.-H. Ortiz-Estrada, J. Gonzalez-Martinez, J.-A. Quezada-Gallo, "Microencapsulati on of coenzyme $\mathrm{Q}(10)$ in poly(ethylene glycol) and poly(lactic acid) with supercritical carbon dioxide", Ind. Eng. Chem. Res., vol.51, no.17, pp.5840-5846, 2012.

[198] X. Jiang, Y.-B. Jiang, C. J. Brinker, "Hydrothermal synthesis of monodisperse single-crystalline alpha-quartz nanospheres ", Chem Commun, vol.47, no.26, pp.7524-7526, 2011.

[199] M. A. Amezcua-Allieri, M. A. Avila-Chavez, A. Trejo, J. Melendez-Estrada, "Removal of polycyclic aromatic hydrocarbons from soil: A comparison between bioremoval and supercritical fluids extraction", Chemosphere, vol.86, no.10, pp.985-993, 2012.

[200] M. Antonio Avila-Chavez, A. Trejo, "Remediation of soils contaminated with total petroleum hydrocarbons and polycyclic aromatic hydrocarbons: Extraction with supercritical ethane", Ind. Eng. Chem. Res., vol.49, no.7, pp.3342-3348, 2010.

[201] A. Lopez-Luna, J. L. Gallegos, M. Gimeno, E. Vivaldo-Lima, E. Barzana, "Lipase-catalyzed syntheses of linear and hyperbranched polyesters using compressed fluids as solvent media", J Mol Catal B-Enzym, vol.67, no.1-2, pp.143-149, 2010. 